\title{
Bank Profitability and Debit Card Interchange Regulation: Bank Responses to the Durbin
}

\author{
Amendment*
}

\author{
Benjamin $\mathrm{Kay}^{\dagger}$
}

Mark D. Manuszak ${ }^{\ddagger}$

Cindy M. Vojtech ${ }^{\S}$

Current Version March 2014 (Original January 2013)

${ }^{*}$ For helpful questions and comments we thank Wilko Bolt, W. Scott Frame, Krzysztof Wozniak, and seminar participants at the Federal Reserve Board, the Department of Treasury, the International Banking, Economics, and Finance Association Seattle 2013 Conference, and the Conference on New Perspectives on Consumer Behavior in Credit and Payment Markets 2013 (Federal Reserve Bank of Philadelphia). Jane Brittingham provided outstanding research assistance. All remaining errors are our own. The views and opinions expressed in this paper are solely the responsibility of the authors and should not be interpreted as reflecting the official policy or position of the Department of Treasury, any agency of the U.S. Government, the Board of Governors of the Federal Reserve System, or anyone else associated with the Federal Reserve System.

${ }^{\dagger}$ Department of Treasury, Office of Financial Research; benjamin.kay@treasury.gov

${ }_{\ddagger}^{\ddagger}$ Federal Reserve Board; mark.d.manuszak@frb.gov

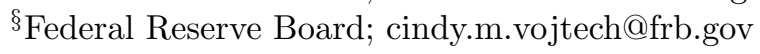


Bank Profitability and Debit Card Interchange Regulation:

Bank Responses to the Durbin Amendment

\begin{abstract}
The Durbin Amendment to the Dodd-Frank Wall Street Reform and Consumer Protection Act of 2010 alters the competitive structure of the debit card payment processing industry and caps debit card interchange fees for banks with over $\$ 10$ billion in assets. Market participants predicted that noninterest income and total bank income would fall but that account fees would rise to offset the loss of income. Some participants also predicted that banks would cut costs in response to the law by reducing staff and shutting down branches. Using a difference-in-differences testing strategy, we show that debit interchange fee income and noninterest income falls for treated banks. We also find evidence that banks were able to partially offset this loss with deposit fees. We find no evidence of cost reduction by treated banks nor that banks strategically avoided the $\$ 10$ billion threshold. We argue that these effects are consistent with predictions from theory.
\end{abstract}

JEL: L13, L51, L84, G18, G21, G23, G28 


\section{Introduction}

The emergence of debit cards has been one of the most notable developments in consumer banking and the retail payments industry in recent decades. Since their introduction in the late 1970s, debit cards have grown to become the most popular noncash retail payment instrument by number of transactions. This growth has been particularly pronounced over the last decade, with both the number and value of debit card transactions growing by approximately 15 percent per year. In contrast, more traditional payment methods, such as credit cards and checks, have experienced lower growth or outright declines Gerdes and Walton 2002; Federal Reserve System 2011).

This growth has been accompanied by controversy over the fees and terms faced by recipients of debit card payments. As with any payment medium, the success of debit cards has depended on the ability to attract both consumers and merchants (Rochet and Tirole 2002). For consumers, the attractiveness of debit cards reflects their low cost, high speed, ease of use, and wide acceptance relative to other payment methods Schuh and Stavins 2011). Widespread merchant acceptance of debit cards would appear to be prima facie evidence that merchants experience similar benefits from cards net of costs. However, merchants have historically, and increasingly, objected to certain aspects of the debit card system..$^{1}$

The most prominent merchant objection is over the merchant discount, the fee a merchant pays to its bank for each debit card transaction. ${ }^{2}$ The most significant component of this fee, the interchange fee, is set by a card network and paid by the merchant's bank to the cardholder's bank for its role in processing the transaction. In aggregate these fees are significant. In 2010, interchange income was about 5 percent of total noninterest income for banks in our data.

The Durbin Amendment to the Dodd-Frank Wall Street Reform and Consumer Protection Act of 2010 (hereafter, Dodd-Frank Act) represents an attempt at using the political

\footnotetext{
${ }^{1}$ Similar high-profile debates have concerned credit cards, although merchants have increasingly drawn attention to issues related to debit cards due to the significant growth in debit card usage.

${ }^{2}$ Additional information about the organization of the debit card industry is provided in the next section.
} 
process to solve this conflict between merchants, banks, and networks over interchange fees. The amendment gives the Board of Governors of the Federal Reserve System (hereafter, Board) the power to regulate interchange fees. As implemented by the Board's Regulation II (hereafter, Reg II), the new regulation caps debit card interchange fees for certain transactions at 21 cents plus 0.05 percent of the transaction value. This cap provides a significant reduction to prevailing interchange fees, about a 45 percent decline per transaction, on average, for covered transactions.

Although the Durbin Amendment was largely motivated by concerns about high interchange fees and high merchant fees, much of the debate over the amendment has focused on its potential effects on cardholder fees. The theoretical literature on interchange fees emphasizes that, just as merchant banks incorporate interchange fees into merchant transaction fees, so too will cardholder banks alter the fees and terms for their customers in response to the subsidy generated by interchange fees (Rochet and Tirole 2002; Bedre-Defolie and Calvano 2013). A similar phenomenon has been examined in the telecommunications markets where changes in interconnection fees between fixed and mobile networks can generate changes in the fees for subscribers to those networks, a possibility which has been termed the "waterbed" effect in that setting Genakos and Valletti 2011). Agarwal, Chomsisengphet, Mahoney, and Stroebel (2014) consider a similar possibility for credit cards following the implementation of the CARD Act's restrictions on certain credit card fees and various practices of credit card-issuing banks.

In this paper, we examine several bank profitability effects of the interchange fee restrictions. We do so by looking at related expenses and revenue measures as reported in the income statement and balance sheet information that banks file with their regulators. Some of these income and expense components that we consider, such as interchange income, are directly affected by Reg II. Others, such as fees for account holders, are indicative of efforts by banks to mitigate the regulation's effects, akin to the "waterbed" effect that has been proposed in telecommunications and elsewhere. We also examine operational statistics, such as the number of employees and branches, for evidence of mitigation efforts in the form of operational cost cutting.

To identify the effects of the regulation, we rely upon the Durbin Amendments exemption 
for smaller depository institutions. Under this exemption, only banks with consolidated assets greater than $\$ 10$ billion are treated by the interchange fee cap. We use this threshold to estimate the effect of the regulation in a differences-in-differences setting. By looking at successively higher levels of aggregation for the income statement items, we are able to examine the success of various measures to offset lost interchange income, particularly deposit fee changes for account holders, as well as the overall net effect of the regulation.

Overall, we find a series of results that are robust to various specifications. First, Reg II clearly led to significant reductions in interchange income for treated banks. While not necessarily surprising given other evidence that card networks decreased debit card interchange fee rates for treated banks to reflect the regulation (Federal Reserve Board 2013), this finding indicates that treated banks have been unable to offset the lost interchange income on debit cards by higher debit volumes or by shifting consumers to credit cards that have unregulated fees. Second, we find that treated banks increased their deposit fees in response to the regulation. While these increases are generally insufficient to mitigate all of the lost interchange income, changes in deposit fees offset roughly 30 percent of the lost interchange income. Indeed, income is generally lower for treated banks at more aggregate measures such as total noninterest income, consistent with incomplete mitigation. Third, we do not find evidence that treated banks decreased their noninterest (operating) expenses following the law nor that banks adjusted other aspects of their operations, such as reducing employees or closing branches.

The remainder of the paper is organized as follows. Section 2 provides background on the debit card industry, the Durbin Amendment, and Reg II. The last part of section 2 relates the debit card environment and the new debit card regulation to economic theory. Section 3 describes the data and presents some summary statistics. Section 4 shows our various empirical results including our robustness checks. Section 5 concludes. 


\section{The Debit Card Industry, the Durbin Amendment, and Theory}

Figure 1 illustrates the basic structure of a debit card system and transaction ${ }^{3}$ A transaction involves five main parties: the consumer, the consumer's bank (the issuer), the merchant, the merchant's bank (the acquirer), and the card network. The banks provide various products and services to their respective customers. The issuing bank offers a deposit account and a debit card to the consumer, and the acquiring bank offers card technology and processing activities to the merchant. The network establishes rules for card transactions and coordinates the transmission of information and funds between the two banks.

Figure 1: Overview of a Debit Card Transaction

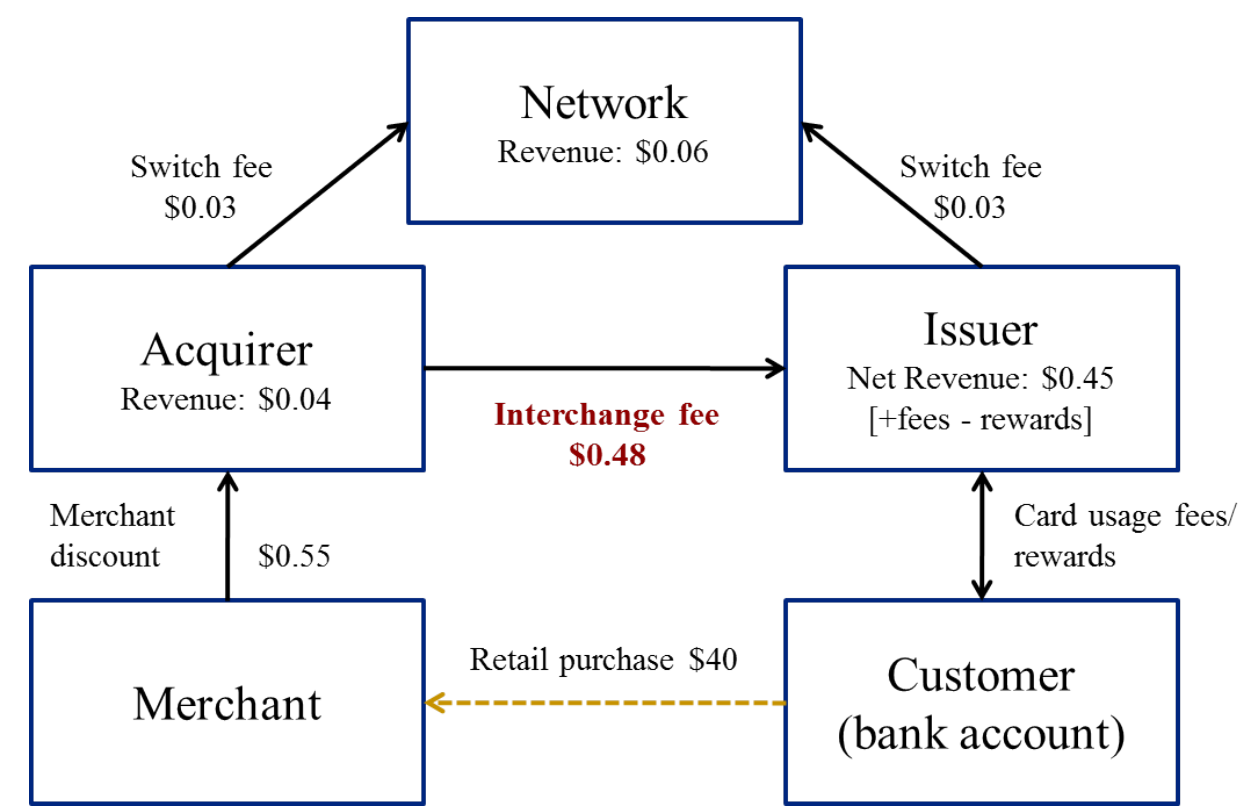

Note: Numbers are illustrative of the types of fees that would be charged in a transaction and their relative magnitudes.

The typical fees for these activities are shown in figure 1. In particular, the two banks separately establish fees and terms for their respective customers associated with debit cards, debit card transactions, and broader account services. For example, the acquirer typically charges a fee to the merchant, known as the merchant discount, for each trans-

\footnotetext{
${ }^{3}$ For a detailed description of the payment cards industry see Evans and Schmalensee (2004) and Prager, Manuszak, Kiser, and Borzekowski (2009). Hayashi, Sullivan, and Weiner (2006) provide a detailed description of the debit card industry.
} 
action. More tangentially, the consumer may face fees less directly tied to transactions, such as monthly maintenance fees on the debit card associated account. The network further levies certain fees on the two banks, including network membership fees and switch fees for each transaction.

The most controversial such fee, and the primary focus of the Durbin Amendment, is the interchange fee. In a debit transaction, this fee is paid by the acquirer to the issuer and is generally deducted from the amount transferred from the issuer to the acquirer when settled. Interchange fee schedules are set by the network that carries a transaction, such as Visa, MasterCard, or one of the PIN debit networks, and apply equally to all banks that participate in that network. Economically, the interchange fee is a transaction cost for the acquirer and a transaction subsidy for the issuer when its cardholder uses the card. We next describe the regulations resulting from the Durbin Amendment and associated controversies. We then conclude this section with a discussion of the economic effects of the interchange fee in greater detail.

\subsection{Background of the Durbin Amendment}

Merchants have long objected to both the existence and level of interchange fees 4 They argue that the collective setting of interchange fees through networks by otherwise competing banks generates collusive rents for issuers in excess of realistic processing costs. Through the impact of interchange fees on acquirer costs and subsequent merchant discounts, merchants argue that interchange fees serve to inflate their costs of debit card transactions to levels greater than the costs of comparable payment methods, such as checks. In their view, these fees are particularly high for dominant networks whose cards merchants cannot easily refuse. They argue that, due to their inability or unwillingness to set prices that vary by payment method, high merchant transaction fees for cards ultimately generate higher prices for all consumers, including those that utilize other payment methods.

\footnotetext{
${ }^{4}$ For example, see the Reg II comment letter National Retail Federation (2011). See also Katz (2001), Frankel (2007), and Prager, Manuszak, Kiser, and Borzekowski (2009) for overviews of merchant concerns about card systems, including concerns about certain rules that networks impose on merchants.
} 
Payment card networks and banks defend interchange fees as an integral part of a payment card network and an important mechanism behind the vigorous growth in debit card usage over the last decade $5^{5}$ They argue that a common interchange fee facilitates the establishment and maintenance of a system in which many disparate banks participate. Moreover, by providing a revenue stream to issuing banks, these parties argue that interchange fees have allowed those banks to offer attractive fee structures and terms to cardholders, as well as funding promotional activities and the significant fixed costs associated with the system. Finally, financial services firms argue that, even with interchange fees, debit cards do offer significant benefits to merchants and point to widespread merchant acceptance of debit cards as prima facie evidence of those benefits.

These disputes, which have been the impetus for past and ongoing antitrust litigation (Wildfang and Marth 2006), culminated in the addition of the Durbin Amendment to the Dodd-Frank Act ${ }^{6}$ With respect to interchange fees, the main provision of the Durbin Amendment instructed the Federal Reserve Board to prescribe regulations to establish "standards for assessing" whether debit card interchange fees received by issuers for card transactions are "reasonable and proportional to the cost incurred by the issuer with respect to the transaction." 7 When developing these regulations, the Board was further instructed to consider the "incremental cost" of authorizing, clearing, and settling a "particular" debit transaction, and not to consider other costs which are not specific to a particular transaction. In addition, the Board was instructed to consider the functional similarity between debit cards and checks, noting that the latter clear at par in the Federal Reserve system.

The statute contained a number of exemptions from the interchange fee provisions. Importantly for our analysis, the statute exempts small issuers from the interchange fee restrictions, likely due to concerns about the effect of decreased interchange revenue on

\footnotetext{
${ }^{5}$ For example, see the Reg II comment letter American Bankers Association et al. (2011). See also (Evans and Schmalensee 2004).

${ }^{6}$ The full text of the Durbin Amendment is available on page 2068 of Government Printing Office (2010). The Board's press release and text for the proposed and final regulations are in Federal Reserve Board (2010) and Federal Reserve Board (2011a), respectively. Public comments related to the proposal are available at Www.federalreserve.gov/apps/foia/ViewAllComments.aspx?doc_id=R-1404\&doc_ ver=1.

'The Durbin Amendment contains various other provisions that are not the central focus of our paper. Hayashi (2012) and Hayashi (2013) discuss these provisions in more detail.
} 
those institutions $8^{8}$ As a result, under the statute, the interchange regulations established by the Board only apply to issuers that, together with affiliates, have assets in excess of $\$ 10$ billion 9

Following the standard rule-writing process, more details of which are included in appendix A, the Board issued Reg II in June 2011 to implement the Durbin Amendment. Under the regulation, on October 1, 2011, interchange fees for issuers with assets greater than $\$ 10$ billion were capped at 22 cents plus 0.05 percent of the transaction value 10 This cap implies a maximum interchange fee of 24 cents for a $\$ 38$ debit card transaction, a decline of 45 percent from the average value of 44 cents for the same transaction in 2009 prior to the Durbin Amendment (Federal Reserve Board 2011b).

\section{$2.2 \quad$ Theory of Interchange Fees}

Beginning with Baxter (1983) and especially following the seminal work of Rochet and Tirole (2002), a substantial theoretical literature has considered the positive and normative implications of interchange fees in payment card markets. Although the models are often highly stylized, the literature provides some predictions about the possible effects of the regulation that we can consider in our data.11

On the merchant-acquirer side of the market, a cap on interchange fees causes a decrease in the cost of the transactions that a merchant processes through its acquirer. The general theoretical result is that competition among acquirers leads to the pass-through of changes in interchange fees to merchant fees. The net effect of the cap on an acquirer will depend on the pass-through rate of merchant fees, the mix of acquirer-provided transaction services, the elasticities of demand for those services, and any substitution

\footnotetext{
${ }^{8}$ The statute contains additional exemptions for debit cards issued pursuant to a governmentadministered payment program (e.g., Supplemental Nutrition Assistance Program cards) and certain reloadable general-use prepaid cards. Because we do not have information pertaining to these card programs, and because the available information suggests that they are small relative to the total debit card market (Federal Reserve System 2011), we do not exploit these exemptions in our analysis.

${ }^{9}$ Under the language in the statute, the exemption is based on consolidated worldwide assets of a financial institution, including all financial and non-financial affiliates.

${ }^{10}$ Reflecting a provision in the statute, Reg II permits issuers to receive a 1 cent adjustment to the interchange fee cap for fraud-prevention costs. The base value of 22 cents assumes eligibility for this adjustment.

${ }^{11}$ Verdier (2011) and Rysman and Wright 2012) provide useful surveys of this literature.
} 
between them when merchant fees change 12

On the consumer-issuer side of the market, by decreasing the subsidy that an issuer receives for each transaction, the interchange cap effectively decreases the issuer's revenue from debit card transactions. As on the merchant side of the market, competition among issuers leads to the pass-through of changes in interchange fees in the fees and terms faced by cardholders. For example, rather than focusing on only transaction-based fees, an issuer could alter fees and terms associated with the debit card or the deposit account associated with the card, such as reward programs, annual card fees, account maintenance fees, higher minimum balances, or changes in interest rates on deposits ${ }^{13}$ Finally, an issuer could look to shift customers to other products, such as credit cards, that are not subject to fee regulation. The net effect of the cap on an issuer will depend on the passthrough of changes in interchange fees on account holder fees, the elasticities of demand for debit card transactions and other products, and any changes in quantities demanded that result from changes in fees.

The effect on any individual bank could depend on the mix of issuing and acquiring that the bank performs. In principle, these multiple activities within a single bank complicate our empirical analysis, particularly as our core data do not identify the extent of issuing or acquiring activity at individual banks. From a practical perspective, however, we view this complication as a relatively minor issue. First, many of the largest acquirers, such as First Data, are not actually banks.14 As a result, much of the movement in merchant discount income and interchange expenses for acquirers will occur for firms that are not in our bank-centric data. Although this data limitation implies that our analysis will not provide a comprehensive view of adjustments in response to Reg II, it also implies that our data will not be significantly corrupted by a co-mingling of issuer and acquirer information. Second, banks that are directly involved in acquiring tend to be large firms, such as Bank of America or J.P. Morgan Chase, reflecting the significant scale economies

\footnotetext{
${ }^{12}$ Ultimately, the change in merchant fees will affect retail prices and merchant profits, but given the bank-centric nature of our analysis, this important issue is beyond the scope of this paper.

13 Sullivan (2013) looks specifically the impact of Reg II on checking account fees and finds that on net customers have more access to free checking accounts from banks that are not treated by the law.

${ }^{14}$ Technically, network rules require participants in card networks to be depository institutions. Firms such as First Data enter into sponsorship agreements with banks in which those banks outsource many or all of the acquiring functions to the sponsored processor. See DeGennaro (2006) or Comptroller of the Currency (2001) for more information.
} 
in the acquiring business. For these firms, our data will reflect effects of lower interchange fees on both issuing and acquiring activities, but any positive effects of imperfect passthrough of lower acquiring costs in merchant discounts will tend to attenuate the negative effects on the issuing parts of the firms. Our robustness checks excluding these largest banks give similar results to our results that include them, consistent with a high level of pass-through of acquirer costs to merchants.

\section{Data}

Our analysis uses quarterly data between 2008:Q1 and 2013:Q2 on bank holding companies (BHCs) and standalone commercial banks (i.e., banks that are not part of a holding company). We focus on observations at this level, rather than individual banks under a holding company, for two reasons. First, the asset threshold of the law is tied to an institution's consolidated assets, which correspond to the assets of the top BHC for institutions with that corporate structure or those of the standalone bank when no holding company exists. Second, both BHCs and standalone banks have significant reporting requirements, which enable us to study behavior at the same level of aggregation as the regulation. Hereafter, the term "bank" will be used to describe both BHCs and standalone banks in the data.

A significant portion of our data comes from mandated reports that financial institutions file quarterly with their regulators. For BHCs, we collect data from the quarterly FR Y-9C, which is filed by BHCs with assets in excess of $\$ 500$ million. For standalone banks, we gather information from the commercial bank quarterly report (Call Report) for banks that are larger than $\$ 500$ million. Broadly speaking, these reports contain detailed income statement and balance sheet information for financial institutions, and we extract a series of income and expense variables that reflect various levels of aggregation of an institution's activities that may be affected by Reg II. In particular, we make novel use of measures relating to interchange and deposit income and related expenses ${ }^{15}$ We then consider

\footnotetext{
${ }^{15}$ Interchange income is subject to a threshold of materiality; firms are only required to report interchange income for amounts greater than $\$ 25,000$ that exceed 3 percent of the higher-level income variable "other non-interest income." Several firms report interchange income even when these thresholds are not met. As we subsequently discuss, our results are robust to our handling of these voluntary reporters.
} 
more aggregate income and expense measures of which interchange and deposit income are components. Appendix B contains more information about the data and our collection processes including a description of how the various income and expense items roll up into broader measures.

The opportunity to view the consequences of Reg II at different levels of aggregation provides several benefits. First, more aggregate measures are less likely to suffer from misclassification or measurement error. Second, because the economic effects of the law are large relative to carefully selected alternatives, analysis of more granular measures are more likely to show a detectable treatment effect.

We supplement this information with several other sources. First, the Call Report provides quarterly data about the number of deposit accounts and full-time equivalent employees (FTEs). Second, the Federal Deposit Insurance Corporation (FDIC) Summary of Deposits (SOD) provides data on the number of branches for commercial banks. Finally, specific to Reg II, we obtain information about the exempt (not-treated) and non-exempt (treated) status of commercial banks from lists that the Board has issued annually since 2011. To establish the status of BHCs, we use relationship data documented by the National Information Center to connect the banks to the controlling BHC.

Using these data, we construct two families of panels consisting of firms for which a year-over-year log difference (growth rate) of a variable can be calculated for at least four quarters between 2011 and 2012. For annual data (SOD and year-to-date income and expense items), the panel requirement is for a firm to at least report valid levels information for 2010, 2011, and 2012. This ensures that firms included are present around the time of the law change. The first family of panels is the Consistent Panel that includes the 688 firms that report required values for all nine primary income and expense variables ${ }^{16}$ These firms are those that are consistently in all of the primary income and expense regressions. The second family consists of individual panels for each variable we study. For example, one panel in the second family is the Interchange Income Panel that includes 700 firms that report valid values for $\ln \left(\right.$ interchange income $\left._{t}\right)-\ln \left(\right.$ interchange income $\left._{t-4}\right)$ for at least four quarters between 2011 and 2012. The panels for these individual variables

\footnotetext{
${ }^{16}$ The nine primary variables are those listed in table 1
} 
range from 700 to 1,047 firms.

Key summary statistics for the Consistent Panel are shown in table 1. Quarterly income and expense variables are organized by treatment group. The table presents information about the levels of the variables for two specific quarters: the first quarter that Reg II is in effect (2011:Q4) and the quarter one full year before (2010:Q4) ${ }^{17}$

Table 1: Table of Means

\begin{tabular}{|c|c|c|c|c|c|c|c|}
\hline & \multicolumn{4}{|c|}{ Levels (000) } & \multicolumn{2}{|c|}{ Log Differences } & \multirow{3}{*}{$\begin{array}{l}\text { Difference- } \\
\text { In-Difference }\end{array}$} \\
\hline & \multicolumn{2}{|c|}{$\begin{array}{c}\text { Not-Treated Firms } \\
\text { (407 Firms) }\end{array}$} & \multicolumn{2}{|c|}{$\begin{array}{c}\text { Treated Firms } \\
\text { (47 Firms) }\end{array}$} & \multirow{2}{*}{$\begin{array}{l}\text { Not-Treated } \\
\text { Firms }\end{array}$} & \multirow{2}{*}{$\begin{array}{l}\text { Treated } \\
\text { Firms }\end{array}$} & \\
\hline & Pre-Law & Post-Law & Pre-Law & Post-Law & & & \\
\hline & $\begin{array}{c}\text { 2010:Q4 } \\
1\end{array}$ & $\begin{array}{l}\text { 2011:Q4 } \\
2\end{array}$ & $\begin{array}{l}\text { 2010:Q4 } \\
3\end{array}$ & $\begin{array}{l}\text { 2011:Q4 } \\
4\end{array}$ & $\begin{array}{l}\text { 2011:Q4 } \\
5\end{array}$ & $\begin{array}{l}\text { 2011:Q4 } \\
6\end{array}$ & 7 \\
\hline Interchange Income & $\begin{array}{c}629 \\
(1,277)\end{array}$ & $\begin{array}{c}681 \\
(1,307)\end{array}$ & $\begin{array}{c}115,131 \\
(302,461)\end{array}$ & $\begin{array}{c}91,717 \\
(238,621)\end{array}$ & $\begin{array}{l}0.126 \\
(0.390)\end{array}$ & $\begin{array}{l}-0.261 \\
(0.496)\end{array}$ & -0.387 \\
\hline Deposit Fees & $\begin{array}{c}1,535 \\
(3,695)\end{array}$ & $\begin{array}{c}1,503 \\
(3,712)\end{array}$ & $\begin{array}{c}119,741 \\
(279,819)\end{array}$ & $\begin{array}{c}126,249 \\
(297,238)\end{array}$ & $\begin{array}{l}-0.043 \\
(0.191)\end{array}$ & $\begin{array}{c}0.018 \\
(0.153)\end{array}$ & 0.061 \\
\hline $\begin{array}{l}\text { Core Other Noninterest } \\
\text { Income }\end{array}$ & $\begin{array}{c}984 \\
(1,677)\end{array}$ & $\begin{array}{c}1,065 \\
(1,631)\end{array}$ & $\begin{array}{c}141,271 \\
(345,791)\end{array}$ & $\begin{array}{c}117,339 \\
(283,689)\end{array}$ & $\begin{array}{c}0.085 \\
(0.299)\end{array}$ & $\begin{array}{l}-0.121 \\
(0.430)\end{array}$ & -0.205 \\
\hline $\begin{array}{l}\text { Core Total Noninterest } \\
\text { Income }\end{array}$ & $\begin{array}{c}3,870 \\
(6,551)\end{array}$ & $\begin{array}{c}3,850 \\
(6,476)\end{array}$ & $\begin{array}{c}693,809 \\
(2,023,087)\end{array}$ & $\begin{array}{c}591,803 \\
(1,692,371)\end{array}$ & $\begin{array}{l}-0.001 \\
(0.214)\end{array}$ & $\begin{array}{l}-0.072 \\
(0.192)\end{array}$ & -0.071 \\
\hline Core Revenue & $\begin{array}{c}17,581 \\
(18,344)\end{array}$ & $\begin{array}{c}17,908 \\
(18,793)\end{array}$ & $\begin{array}{c}1,916,518 \\
(4,926,321)\end{array}$ & $\begin{array}{c}1,806,469 \\
(4,420,012)\end{array}$ & $\begin{array}{c}0.014 \\
(0.094)\end{array}$ & $\begin{array}{c}0.037 \\
(0.190)\end{array}$ & 0.023 \\
\hline $\begin{array}{l}\text { Other Noninterest } \\
\text { Expense }\end{array}$ & $\begin{array}{c}4,709 \\
(5,341)\end{array}$ & $\begin{array}{c}4,556 \\
(5,213)\end{array}$ & $\begin{array}{c}575,007 \\
(1,556,994)\end{array}$ & $\begin{array}{c}586,185 \\
(1,512,846)\end{array}$ & $\begin{array}{l}-0.039 \\
(0.303)\end{array}$ & $\begin{array}{c}0.052 \\
(0.312)\end{array}$ & 0.091 \\
\hline $\begin{array}{l}\text { Total Noninterest } \\
\text { Expense }\end{array}$ & $\begin{array}{c}13,451 \\
(14,737)\end{array}$ & $\begin{array}{c}13,732 \\
(15,742)\end{array}$ & $\begin{array}{c}1,508,849 \\
(4,092,742)\end{array}$ & $\begin{array}{c}1,525,164 \\
(3,844,323)\end{array}$ & $\begin{array}{c}0.003 \\
(0.232)\end{array}$ & $\begin{array}{c}0.093 \\
(0.235)\end{array}$ & 0.090 \\
\hline Salaries & $\begin{array}{c}6,743 \\
(7,931)\end{array}$ & $\begin{array}{l}7,097 \\
(8,806)\end{array}$ & $\begin{array}{c}679,379 \\
(1,838,340)\end{array}$ & $\begin{array}{c}690,093 \\
(1,817,099)\end{array}$ & $\begin{array}{c}0.033 \\
(0.129)\end{array}$ & $\begin{array}{c}0.092 \\
(0.176)\end{array}$ & 0.058 \\
\hline Premises & $\begin{array}{c}1,675 \\
(1,931)\end{array}$ & $\begin{array}{c}1,679 \\
(2,007)\end{array}$ & $\begin{array}{c}165,154 \\
(431,586)\end{array}$ & $\begin{array}{c}162,124 \\
(415,007)\end{array}$ & $\begin{array}{l}-0.015 \\
(0.273)\end{array}$ & $\begin{array}{c}0.057 \\
(0.173)\end{array}$ & 0.071 \\
\hline
\end{tabular}

Standard deviations are in parentheses.

Table 1 illustrates several notable features of the data. First, treated and not-treated banks exhibit very different values for the levels of every variable, as seen in columns 1 to 4 . Given that the threshold condition for not-treated status is based on firm size, and size is highly positively correlated with many of the variables that we consider, these differences are expected. Second, firms within each group exhibit substantial heterogeneity.

Finally, the last column highlights some of our basic regression results from the next section. In particular, for firms subject to the interchange fee restrictions, interchange income fell sharply, core other noninterest income fell substantially, and deposit fee income rose to partially offset the loss in interchange income. However, core total noninterest income still declined. Additionally, treated banks do not appear to have cut their ex-

\footnotetext{
${ }^{17}$ In order to keep a balanced set of firms, only Consistent Panel members that have all the data for both quarters are presented in table 1
} 
penses. The next section documents these findings using data from our full sample and examines the robustness of those results to different samples and specifications.

\section{Empirical Results and Testing}

For the nine primary testing variables we estimate four quarterly first difference models (two panels $\times$ two specifications). The basic estimating equation is

$$
\Delta y_{i, t}=\lambda_{t}+\tau \cdot \Delta \text { Treat }_{i, t}+\Delta u_{i, t}
$$

where $\Delta y_{i, t}$ is the first difference in log interchange income $\left(\ln y_{i, t}-\ln y_{i, t-4}\right), \lambda_{t}$ is a common date-specific effect, $\Delta$ Treat $_{i, t}=1$ if firm $i$ is subject to the regulation at time $t$ and not in $t-4$ (an interaction of treated time with treated firm), $\tau$ is the effect of the policy on firm $i$, and $\Delta u_{i, t}$ is the error term. The alternative estimating equation is

$$
\Delta y_{i, t}=g_{i} \mathbf{1}_{i}+\lambda_{t}+\tau \cdot \Delta \text { Treat }_{i, t}+\Delta u_{i, t}
$$

where $g_{i}$ is a firm-specific growth trend. For each of these specifications, we consider two families of panels as discussed in section 3 .

\subsection{Income Reactions}

\section{Interchange Income}

Because reporting interchange income is only required above a certain threshold, the two interchange income panels tested are subsamples of firms particularly likely to be affected by the law. It is also important to note that interchange income is reported as the combination of debit card and credit card interchange income.

Table 2 shows the four interchange income regression results. Columns 1 and 2 use equation (1); columns 3 and 4 use equation (2). The coefficient of interest is $\tau$ (Durbin $\times$ Treat). The estimated effect of the Durbin Amendment on treated firms' interchange income 
Table 2: Interchange Income Regressions

\begin{tabular}{|c|c|c|c|c|}
\hline Variables & $\begin{array}{c}\text { Consistent } \\
1\end{array}$ & $\begin{array}{c}\text { Interchange Inc. } \\
2\end{array}$ & $\begin{array}{c}\text { Consistent } \\
3\end{array}$ & $\begin{array}{c}\text { Interchange Inc. } \\
4\end{array}$ \\
\hline Durbin $\times$ Treat & $\begin{array}{r}-0.412^{* * *} \\
(0.0492)\end{array}$ & $\begin{array}{r}-0.420^{* * *} \\
(0.0541)\end{array}$ & $\begin{array}{r}-0.405^{* * *} \\
(0.0490)\end{array}$ & $\begin{array}{r}-0.409^{* * *} \\
(0.0508)\end{array}$ \\
\hline Constant & $\begin{array}{r}0.142^{* * *} \\
(0.0274)\end{array}$ & $\begin{array}{r}0.141^{* * *} \\
(0.0272)\end{array}$ & $\begin{array}{r}0.149^{* * *} \\
(0.0264)\end{array}$ & $\begin{array}{r}0.149^{* * *} \\
(0.0263)\end{array}$ \\
\hline Fixed Effects? & No & No & Yes & Yes \\
\hline Observations & 10,169 & 10,330 & 10,169 & 10,330 \\
\hline Firms & 688 & 700 & 688 & 700 \\
\hline R-squared & 0.023 & 0.024 & 0.215 & 0.218 \\
\hline Adj. R-squared & 0.021 & 0.023 & 0.157 & 0.160 \\
\hline
\end{tabular}

ranges between a log difference of -0.41 and -0.42 . This translates into a decline in interchange income of approximately 34 percent 18 Although interchange income is not separately reported for credit cards and debit cards, the data suggest debit interchange income was about 90 percent of the pre-law total interchange income for treated firms. ${ }^{19}$ While it was possible for the debit interchange income decrease to be partially offset by both higher volumes and credit card interchange income, the overall impact was a significant and seemingly permanent impact.

As mentioned above, many firms report interchange income even if the reporting threshold is not passed. To check for possible reporting bias, we rerun the tests shown in table 2 but exclude banks with interchange income below the threshold. This lowers the number of firms in the Consistent and Interchange Income Panels by 36 and 38, respectively. These tests are reported in appendix C.1. The results are similar. Interchange income declines

\footnotetext{
${ }^{18}$ Note that while economists frequently interpret $\log$ differences as percent growth rates, that interpretation relies upon the approximation $\ln (1+r) \approx r$ which only holds well in the range of \pm 0.30 . Because the estimated effects here are outside that bound we report the results after converting them to percentages with $\tau \%=e^{\tau}-1$.

${ }^{19}$ Debit revenue declined by $\delta \approx 45$ percent per transaction $(\$ 0.44$ to $\$ 0.24)$ while overall interchange income fell by $\xi \approx 34$ percent. This tells us:

$$
\begin{gathered}
D_{t+1}+C_{t+1}=(1-\xi)\left(D_{t}+C_{t}\right) \\
D_{t+1}=(1+g)(1-\delta) D_{t}
\end{gathered}
$$

If debit and credit transactions at a given firm grew at the same rate $g \approx 12$ percent then debit interchange is $\approx 91$ percent of total interchange income. If instead, credit transactions are assumed to grow at 5 percent and debit still at 12 percent, the estimated debit share of all interchange income is 88 percent.
} 
in the range of 31 to 33 percent.

Table 3: Net Interchange Regressions

\begin{tabular}{|c|c|c|c|c|}
\hline Variables & $\begin{array}{c}\text { Consistent } \\
1\end{array}$ & $\begin{array}{c}\text { Net Interchange } \\
2\end{array}$ & $\begin{array}{c}\text { Consistent } \\
3\end{array}$ & $\begin{array}{c}\text { Net Interchange } \\
4\end{array}$ \\
\hline Durbin $\times$ Treat & $\begin{array}{r}-0.463^{* * *} \\
(0.0650)\end{array}$ & $\begin{array}{r}-0.469^{* * *} \\
(0.0673)\end{array}$ & $\begin{array}{r}-0.450^{* * *} \\
(0.0638)\end{array}$ & $\begin{array}{r}-0.451^{* * *} \\
(0.0642)\end{array}$ \\
\hline Constant & $\begin{array}{r}0.0259 \\
(0.0340)\end{array}$ & $\begin{array}{r}0.0272 \\
(0.0338)\end{array}$ & $\begin{array}{r}0.0232 \\
(0.0353)\end{array}$ & $\begin{array}{r}0.0253 \\
(0.0350)\end{array}$ \\
\hline Fixed Effects? & No & No & Yes & Yes \\
\hline Observations & 8,896 & 9,063 & 8,896 & 9,063 \\
\hline Firms & 621 & 635 & 621 & 635 \\
\hline R-squared & 0.033 & 0.034 & 0.166 & 0.169 \\
\hline Adj. R-squared & 0.031 & 0.032 & 0.102 & 0.104 \\
\hline
\end{tabular}

Following the enactment of Reg II, many banks ended debit card rewards programs, so part of the mitigation came from a reduction in expenses. However, these expenses are not clearly reported in the $\mathrm{Y}-9 \mathrm{C}{ }^{20}$ To create a consistent measure of interchange across all banks, we rerun the regressions using the log difference of net interchange which equals interchange income (item HI M.6(g)) minus automated teller machine (ATM) and interchange expenses ("interchange expense," item HI M.7(j)). While this revised variable should contain a more consistent measure of interchange-related cash flows across banks, the calculation introduces noise from ATM expenses.

Table 3 reports the regression results. After the coefficients are converted to growth rates, the results show that net interchange falls 36 to 37 percent for treated firms under Reg II. Given the similar results and that many banks report a relatively low value for interchange expense, it appears that banks tend to report interchange income net of reward expenses ${ }^{21}$

\section{Deposit Fees}

\footnotetext{
${ }^{20}$ See appendix B.3 for more information.

${ }^{21}$ We also explore the possibility that banks separately report merchant income or merchant expense. Specifically, we examine the three free text fields in other noninterest income (5.1) and other noninterest expense (7.d). Of the 39 banks that consistently report merchant-related income for 2010, 2011, and 2012, there is no apparent change in behavior after Reg II. Only 9 banks consistently report a merchant-related expense item for those same years, and again, there is no apparent change in behavior.
} 
The press prominently reported banks announcing their intention to raise fees to offset lost interchange revenue. However, the press later reported the high profile retreats of Bank of America, Wells Fargo, and others over such announced fees. Banks may announce deposit fee increases and not implement them or implement deposit fee increases without announcing them.

Table 4: Deposit Fees Regressions

\begin{tabular}{|c|c|c|c|c|}
\hline Variables & $\begin{array}{c}\text { Consistent } \\
1\end{array}$ & $\begin{array}{c}\text { Deposit Fees } \\
2\end{array}$ & $\begin{array}{c}\text { Consistent } \\
3\end{array}$ & $\begin{array}{c}\text { Deposit Fees } \\
4\end{array}$ \\
\hline Durbin $\times$ Treat & $\begin{array}{r}0.0401^{* *} \\
(0.0177)\end{array}$ & $\begin{array}{c}0.0334^{*} \\
(0.0198)\end{array}$ & $\begin{array}{r}0.0262 \\
(0.0192)\end{array}$ & $\begin{array}{r}0.0469 * \\
(0.0253)\end{array}$ \\
\hline Constant & $\begin{array}{r}-0.00156 \\
(0.00800)\end{array}$ & $\begin{array}{r}0.00102 \\
(0.00879)\end{array}$ & $\begin{array}{r}0.00278 \\
(0.00767)\end{array}$ & $\begin{array}{r}0.00825 \\
(0.00884)\end{array}$ \\
\hline Fixed Effects? & No & No & Yes & Yes \\
\hline Observations & 11,425 & 16,630 & 11,425 & 16,630 \\
\hline Firms & 688 & 1,019 & 688 & 1,019 \\
\hline R-squared & 0.028 & 0.017 & 0.245 & 0.229 \\
\hline Adj. R-squared & 0.027 & 0.016 & 0.195 & 0.178 \\
\hline
\end{tabular}

Indeed, table 4 provides some evidence that firms were able to increase deposit fees. ${ }^{22}$ Four specifications are shown, the same ones used for interchange income. Using all of the point estimates, treated firms increased deposit fees 3 to 5 percent after Reg II was in effect.

Table 5: Relationship Between Income Items, Consistent Panel (2010)

\begin{tabular}{|c|c|c|c|c|c|c|c|c|c|}
\hline & \multicolumn{3}{|c|}{ Deposit Fees as a \% of: } & \multicolumn{3}{|c|}{ Interchange as a \% of: } & \multicolumn{3}{|c|}{ Interchange as a \% of: } \\
\hline & & Core Total & Core & Core Other & Core Total & Core & Other & Total & \\
\hline & Interchange & Nonint Inc & Revenue & Nonint Inc & Nonint Inc & Revenue & Nonint Inc & Nonint Inc & Revenue \\
\hline \multicolumn{10}{|c|}{ Treated Firms } \\
\hline Mean & 279 & 36 & 9 & 71 & 20 & 5 & 37 & 15 & 4 \\
\hline St dev. & $(234)$ & (15) & (4) & (21) & (15) & (4) & $(35)$ & (12) & (3) \\
\hline \multicolumn{10}{|c|}{ Not-Treated Firms } \\
\hline Mean & 733 & 46 & 8 & 58 & 16 & 3 & 36 & 15 & 3 \\
\hline St dev. & $(2,513)$ & $(48)$ & (6) & $(62)$ & (11) & (3) & (23) & $(29)$ & $(3)$ \\
\hline \multicolumn{10}{|l|}{ All Firms } \\
\hline Mean & 694 & 45 & 8 & 59 & 17 & 3 & 36 & 15 & 3 \\
\hline St dev. & $(2,407)$ & (46) & (6) & (59) & (12) & (3) & (25) & (28) & (3) \\
\hline
\end{tabular}

Table 5 shows the relative size of income statement items for the Consistent Panel. Since

\footnotetext{
${ }^{22}$ Deposit fees include overdraft fees and account minimum fees among others. See appendix B.4 for the list of 12 categories of fees in the form instructions.
} 
revenues from deposit fees are on average three times higher than interchange income, this indicates that treated banks were able to offset 30 percent of the lost interchange income through higher deposit fees ${ }^{23}$

Given that deposit account services are a bundled product, the cap on interchange fees could be considered a price shock for the treated firms. These firms want to raise fees to offset the marginal cost increase but not all of the competition is treated. Under perfect competition treated firms would have no market power to raise prices and so there would be no offsetting revenue from deposit fees. In contrast, under monopolistic competition, firms have significant scope to pass through price increases to customers. Various sources have indicated that despite high concentrations, banking is quite competitive (Shaffer 1989; Claessens and Laeven 2004). Evidence that treated banks were able to offset 30 percent of lost income challenges that general impression.

Table 6: Growth in Debit Transactions (Log Differences)

\begin{tabular}{lcccr}
\hline & Year & Obs & Mean & $\begin{array}{c}\text { Standard } \\
\text { Deviation }\end{array}$ \\
\hline Treated Firms & & & & \\
& 2009 & 43 & 0.14 & 0.18 \\
& 2010 & 45 & 0.09 & 0.07 \\
& 2011 & 44 & 0.10 & 0.13 \\
Not-Treated Firms & 2012 & 44 & 0.06 & 0.25 \\
& 2009 & 9 & 0.21 & \\
& 2010 & 8 & 0.15 & 0.39 \\
& 2011 & 8 & 0.21 & 0.14 \\
& 2012 & 8 & 0.19 & 0.25 \\
\hline
\end{tabular}

Source: Nilson Reports.

A similar conclusion comes through the transaction volumes. Nilson data on transaction volumes in debit cards indicates that treated firms continued to grow their volumes at 6 percent per year in 2012 (table 6). Normally, price cuts should not lead to greater supply. However, (non-price-discriminating) monopolists can and do respond to price ceilings with greater supply. It is difficult to reconcile these results with the previous

\footnotetext{
${ }^{23}$ Using the Consistent Panel and no fixed effects specification (column 1), interchange income fell $\xi \approx-34$ percent. Deposit fees increased $\zeta=4.0$ percent. The ratio of deposit fees to interchange income among the treated is $\chi \approx 2.79$. Then the fraction offset is:
}

$$
\frac{-\chi \zeta}{\xi}=32.8 \%
$$


literature suggesting that retail banking in highly competitive.

\section{Broader Income Categories}

Viewing the effect of the law on broader income measures allows us to assess its fuller impact. For instance, other noninterest income includes alternative income sources like ATM and safe deposit fees that could have been increased to mitigate Reg II. However, higher level measures contain volatile and large components unrelated to interchange income. To avoid extraordinary items flowing through the income statement, we define "core" income categories by stripping out other noninterest income that is not reported as a standard line item. We also exclude trading revenue, gains (or losses) on asset sales, and changes from fair-value-option accounting. The exact line items defining our core measures are provided in table 14 in appendix B. These definitions focus on the revenues from financial services for which banks might plausibly adjust their prices in response to the law 24

Table 7: Core Income Category Regressions

\begin{tabular}{|c|c|c|c|c|c|c|}
\hline Variables & \multicolumn{2}{|c|}{$\begin{array}{c}\text { Core Other } \\
\text { Noninterest Income } \\
\text { Core Other }\end{array}$} & \multicolumn{2}{|c|}{$\begin{array}{c}\text { Core Total } \\
\text { Noninterest Income } \\
\text { Core Total }\end{array}$} & \multicolumn{2}{|c|}{$\begin{array}{c}\text { Core } \\
\text { Revenue }\end{array}$} \\
\hline Durbin $\times$ Treat & $\begin{array}{r}-0.240^{* * *} \\
(0.0407)\end{array}$ & $\begin{array}{r}-0.245^{* * *} \\
(0.0432)\end{array}$ & $\begin{array}{r}-0.0722^{* * *} \\
(0.0207)\end{array}$ & $\begin{array}{r}-0.0646^{* * *} \\
(0.0193)\end{array}$ & $\begin{array}{r}-0.00268 \\
(0.0175)\end{array}$ & $\begin{array}{r}-0.0127 \\
(0.0150)\end{array}$ \\
\hline Constant & $\begin{array}{r}0.167^{* * *} \\
(0.0217)\end{array}$ & $\begin{array}{r}0.137^{* * *} \\
(0.0197)\end{array}$ & $\begin{array}{r}0.0160 \\
(0.0113)\end{array}$ & $\begin{array}{r}0.00880 \\
(0.0104)\end{array}$ & $\begin{array}{r}0.0301^{* * *} \\
(0.00659)\end{array}$ & $\begin{array}{r}0.0247^{* * *} \\
(0.00690)\end{array}$ \\
\hline Observations & 11,100 & 15,225 & 11,400 & 16,928 & 11,435 & 17,060 \\
\hline Firms & 688 & 976 & 688 & 1,043 & 688 & 1,047 \\
\hline R-squared & 0.021 & 0.011 & 0.007 & 0.004 & 0.012 & 0.012 \\
\hline Adj. R-squared & 0.019 & 0.010 & 0.005 & 0.003 & 0.011 & 0.011 \\
\hline
\end{tabular}

Robust standard errors in parentheses are clustered at the firm level.

Year-quarter dummies are suppressed.

$* * * \mathrm{p}<0.01,{ }^{*} * \mathrm{p}<0.05, * \mathrm{p}<0.10$

Table 7 shows the regression results on these core versions of broader income measures. For space considerations, only two of the four testing specifications are reported (the equivalent of columns 1 and 2 in table 2, no fixed effects). Note in interpreting the

\footnotetext{
${ }^{24}$ The regression results using income measures that include non-core income are reported in appendix B.2 table 17. As described in the appendix, the estimates from those regressions are larger than what is predicted given the relative size of interchange income and the broader income measures tested. Stripping out non-core activity corrects this anomaly.
} 
results: interchange income $\subset$ core other noninterest income $\subset$ core total noninterest income $\subset$ core revenue.

The estimated causal effects on core other noninterest income and core total noninterest income are significant, and they are close to and statistically indistinguishable from the predicted effects of actual changes in interchange income without mitigation. For example, interchange income is 71 percent of core other noninterest income (table 5), and the estimate of interchange income decline is 34 percent. This leads to an estimated decline of core other noninterest income of $0.71 \times 0.34=24$ percent. That is not statistically different than the point estimate of 21 percent $(\exp (-0.240)-1=-0.213)$, implying no mitigation at this level. An important caveat is that while the t-tests have plenty of power to distinguish effects from zero, a modest amount of mitigation on core total noninterest income (like that found in the prior section on deposit fees) cannot be rejected.

The point estimates from the core revenue regressions are negative, but the results are quantitatively low and not statistically significant. These results are sensible given that interchange income was only 5 percent of core revenue for the Consistent Panel before the law (table 5). Also notice that this test has limited power. Core revenue would have had to grow (or shrink) by 3.4 percent in the Consistent Panel to detect a significant effect. The expected effect on the Consistent Panel is 0.05 (fraction of revenue) $\times 0.34$ (reduction in interchange) $=0.017$ or 2 percent, which is well below this threshold for a significant finding. However, the sign and magnitudes of the estimated effects are consistent with this estimate.

\subsection{Expense Reactions and Changes to Operations}

\section{Expense}

Another possible way to pass on the income loss is to adjust (lower) quality. For example, landlords will allow property to go into disrepair when faced with rent controls. Perhaps banking service quality has declined in response to the law. Lower expenditures on salaries, bank facilities (premises), other noninterest expenses, and total noninterest expenses would all be consistent with firms cutting back on costs (and likely quality) in 
Table 8: Expense Regressions

\begin{tabular}{|c|c|c|c|c|c|c|c|c|}
\hline \multirow[b]{2}{*}{ Variables } & \multicolumn{2}{|c|}{ Salaries } & \multicolumn{2}{|c|}{ Premises } & \multicolumn{2}{|c|}{$\begin{array}{c}\text { Other } \\
\text { Noninterest Exp } \\
\text { Other }\end{array}$} & \multicolumn{2}{|c|}{$\begin{array}{c}\text { Total } \\
\text { Noninterest Exp } \\
\\
\text { Total }\end{array}$} \\
\hline & $\begin{array}{c}\text { Consistent } \\
1\end{array}$ & $\begin{array}{c}\text { Salaries } \\
2\end{array}$ & $\begin{array}{c}\text { Consistent } \\
3\end{array}$ & $\begin{array}{c}\text { Premises } \\
4\end{array}$ & $\begin{array}{c}\text { Consistent } \\
5\end{array}$ & $\begin{array}{c}\text { Nonint Exp } \\
6\end{array}$ & $\begin{array}{c}\text { Consistent } \\
7\end{array}$ & $\begin{array}{c}\text { Nonint Exp } \\
8\end{array}$ \\
\hline Durbin $\times$ Treat & $\begin{array}{r}0.0168 \\
(0.0127)\end{array}$ & $\begin{array}{r}0.00941 \\
(0.0102)\end{array}$ & $\begin{array}{r}0.0299 \\
(0.0183)\end{array}$ & $\begin{array}{r}0.0118 \\
(0.0153)\end{array}$ & $\begin{array}{c}0.0417^{*} \\
(0.0242)\end{array}$ & $\begin{array}{r}0.00445 \\
(0.0244)\end{array}$ & $\begin{array}{r}0.0308^{*} \\
(0.0174)\end{array}$ & $\begin{array}{r}0.0161 \\
(0.0155)\end{array}$ \\
\hline Constant & $\begin{array}{r}0.0176^{* * *} \\
(0.00656)\end{array}$ & $\begin{array}{c}0.0110^{* *} \\
(0.00520)\end{array}$ & $\begin{array}{r}0.0543^{* * *} * \\
(0.00697)\end{array}$ & $\begin{array}{r}0.0494^{* * *} \\
(0.00603)\end{array}$ & $\begin{array}{r}0.178^{* * *} \\
(0.00901)\end{array}$ & $\begin{array}{r}0.181^{* * *} * \\
(0.00823)\end{array}$ & $\begin{array}{r}0.0859^{* * *} * \\
(0.00970)\end{array}$ & $\begin{array}{r}0.0841^{* * *} * \\
(0.00785)\end{array}$ \\
\hline Observations & 11,434 & 17,080 & 11,434 & 17,071 & 11,424 & 17,040 & 11,432 & 17,080 \\
\hline Firms & 688 & 1,048 & 688 & 1,048 & 688 & 1,047 & 688 & 1,048 \\
\hline R-squared & 0.013 & 0.011 & 0.008 & 0.004 & 0.098 & 0.074 & 0.017 & 0.016 \\
\hline Adj. R-squared & 0.012 & 0.010 & 0.006 & 0.003 & 0.097 & 0.073 & 0.015 & 0.015 \\
\hline
\end{tabular}

response to the reduced revenue per transaction from the law. Table 8 reports the results of these regressions. All of the point estimates are positive, but most are not statistically different from zero. There is no evidence that treated banks lowered their expenses in response to Reg II.

\section{Branches and Full-Time Equivalent Employees}

The expense regressions did not find evidence that treated firms were using cost reductions to mitigate lost interchange income. Tests using branch counts and the number of FTEs are used to confirm those results. It may be the case that firm restructurings through layoffs and branch closures have increased expenses in the short run and that treated firms are still repositioning product quality given the new environment.

The first two columns of table 9 report the regression results of branch growth using two specifications: with or without fixed effects (equivalent to columns 2 and 4 in table 2]. Under the hypothesis that banks want to decrease operating costs to mitigate loss of interchange income, the expected sign of the interacted variable is negative. Neither estimate has the expected sign, and neither model specification yields coefficients that are statistically different from zero.

Columns 3 and 4 of table 9 show the regression results using bank FTE growth (yearover-year log differences) as the dependent variable. Again, two model specifications are reported: with or without fixed effects. The expected sign is negative under the 
Table 9: Branch Count and FTE Regressions

\begin{tabular}{lrr|rr}
\hline \multirow{2}{*}{ Variables } & \multicolumn{2}{c|}{ Branches } & \multicolumn{2}{c}{ FTEs } \\
\hline \multirow{2}{*}{ Durbin×Treat } & 0.0165 & 0.0114 & 0.0472 & 0.0322 \\
& $(0.0194)$ & $(0.0241)$ & $(0.0316)$ & $(0.0257)$ \\
Constant & $0.0331^{* * *}$ & $0.0369^{* * *}$ & $0.0121^{* *}$ & $0.0157^{* * *}$ \\
& $(0.00417)$ & $(0.00430)$ & $(0.00504)$ & $(0.00468)$ \\
& & & & \\
Fixed Effects? & No & Yes & No & Yes \\
Observations & 3,998 & 3,998 & 9,548 & 9,548 \\
Firms & 852 & 852 & 571 & 571 \\
R-squared & 0.004 & 0.286 & 0.009 & 0.312 \\
Adj. R-squared & 0.003 & 0.092 & 0.007 & 0.267 \\
\hline Robust standan
\end{tabular}

Robust standard errors in parentheses are clustered at the firm level.

Year dummies are suppressed for branch regressions, and year-quarter dummies are suppressed for FTE regressions.

${ }^{* * *} \mathrm{p}<0.01,{ }^{* *} \mathrm{p}<0.05,{ }^{*} \mathrm{p}<0.10$

hypothesis of cost cutting or quality reduction. The signs of both estimates are instead positive but not statistically different from zero. Treated banks do not appear to be adjusting FTEs in response to Reg II.

\section{Number of Accounts}

Given that many treated banks cut their debit card rewards programs and were publicly indicating that deposit fees would go up, one possible effect of Reg II could be customers changing banks. Customers of treated banks could switch to untreated banks. To test this possible effect, we use data on the number of deposit accounts reported by commercial banks in the Call Report.

The length of the panel is limited by the reporting standards. Commercial banks had to report account data quarterly beginning in 2010:Q1 25 Growth rates are again calculated using year-over-year log differences. There are two line items in the Call Report relating to the number of deposit accounts: accounts $\leq \$ 250,000$ (small accounts) and accounts $>\$ 250,000$ (large accounts). Each account type is tested separately as well as the total.

Table 10 shows the regression results. Across all specifications, the coefficient on the variable of interest (Durbin $\times$ Treat) is the wrong sign and is statistically significant at

\footnotetext{
${ }^{25}$ Prior to that, banks only had to report the data annually in the June filing.
} 
Table 10: Number of Accounts Regressions

\begin{tabular}{|c|c|c|c|c|c|c|}
\hline Variables & $\begin{array}{c}\text { Total } \\
\text { Accounts } \\
1\end{array}$ & $\begin{array}{c}\text { Small } \\
\text { Accounts } \\
2\end{array}$ & $\begin{array}{c}\text { Large } \\
\text { Accounts } \\
3\end{array}$ & $\begin{array}{c}\text { Total } \\
\text { Accounts } \\
4\end{array}$ & $\begin{array}{c}\text { Small } \\
\text { Accounts } \\
5\end{array}$ & $\begin{array}{c}\text { Large } \\
\text { Accounts } \\
6\end{array}$ \\
\hline Durbin $\times$ Treat & $\begin{array}{c}0.0308^{*} \\
(0.0178)\end{array}$ & $\begin{array}{c}0.0297^{*} \\
(0.0179)\end{array}$ & $\begin{array}{r}0.116 \\
(0.0915)\end{array}$ & $\begin{array}{r}0.0220 \\
(0.0252)\end{array}$ & $\begin{array}{r}0.0224 \\
(0.0253)\end{array}$ & $\begin{array}{r}0.0823 \\
(0.0793)\end{array}$ \\
\hline Constant & $\begin{array}{r}-0.0107 \\
(0.00808)\end{array}$ & $\begin{array}{r}-0.0110 \\
(0.00822)\end{array}$ & $\begin{array}{r}0.0499^{* * *} \\
(0.0131)\end{array}$ & $\begin{array}{r}-0.00959 \\
(0.00770)\end{array}$ & $\begin{array}{r}-0.00989 \\
(0.00788)\end{array}$ & $\begin{array}{r}0.0523^{* * *} \\
(0.0123)\end{array}$ \\
\hline Fixed Effects? & No & No & No & Yes & Yes & Yes \\
\hline Observations & 5,480 & 5,480 & 5,479 & 5,480 & 5,480 & 5,479 \\
\hline Firms & 569 & 569 & 569 & 569 & 569 & 569 \\
\hline R-squared & 0.002 & 0.002 & 0.019 & 0.269 & 0.267 & 0.414 \\
\hline Adj. R-squared & 0.000 & 0.000 & 0.017 & 0.183 & 0.181 & 0.345 \\
\hline
\end{tabular}

the 10 percent level for two of the specifications. Using the point estimate, the results indicate that large banks gained customers following the implementation of Reg II, and the gain was driven by small accounts.

\subsection{Robustness Checks on Income and Expense Reactions}

\section{Limiting Sample to Firms Around the $\$ 10$ Billion Threshold}

Identification with the difference-in-differences methodology hinges on constant trends in the treated and untreated firms in the absence of the Durbin Amendment. However, since the analysis is in log differences, in this setting the trend is in growth rates. While table 6 shows that the not-treated firms have been growing their debit transactions faster than treated firms, the difference in growth rates between the two groups is small relative to within-group variation. Unfortunately, we only have transaction count information for 54 firms in our data, and this is a subsample of firms with particularly large numbers of debit customers. The concern remains: Are firms much smaller or much larger than the $\$ 10$ billion threshold similar enough to warrant this assumption of common trend? This also raises issues of external validity. If firms are substantially different among unobservables when moving far away from the treatment threshold, it may not be plausible to 
interpret $\tau$ (treatment effect) as a good estimate of the effect a Durbin-like reduction on interchange fees for those more extreme banks.

Figure 2: Coefficient Sensitivity to Changing Sample, Near $\$ 10$ Billion Threshold

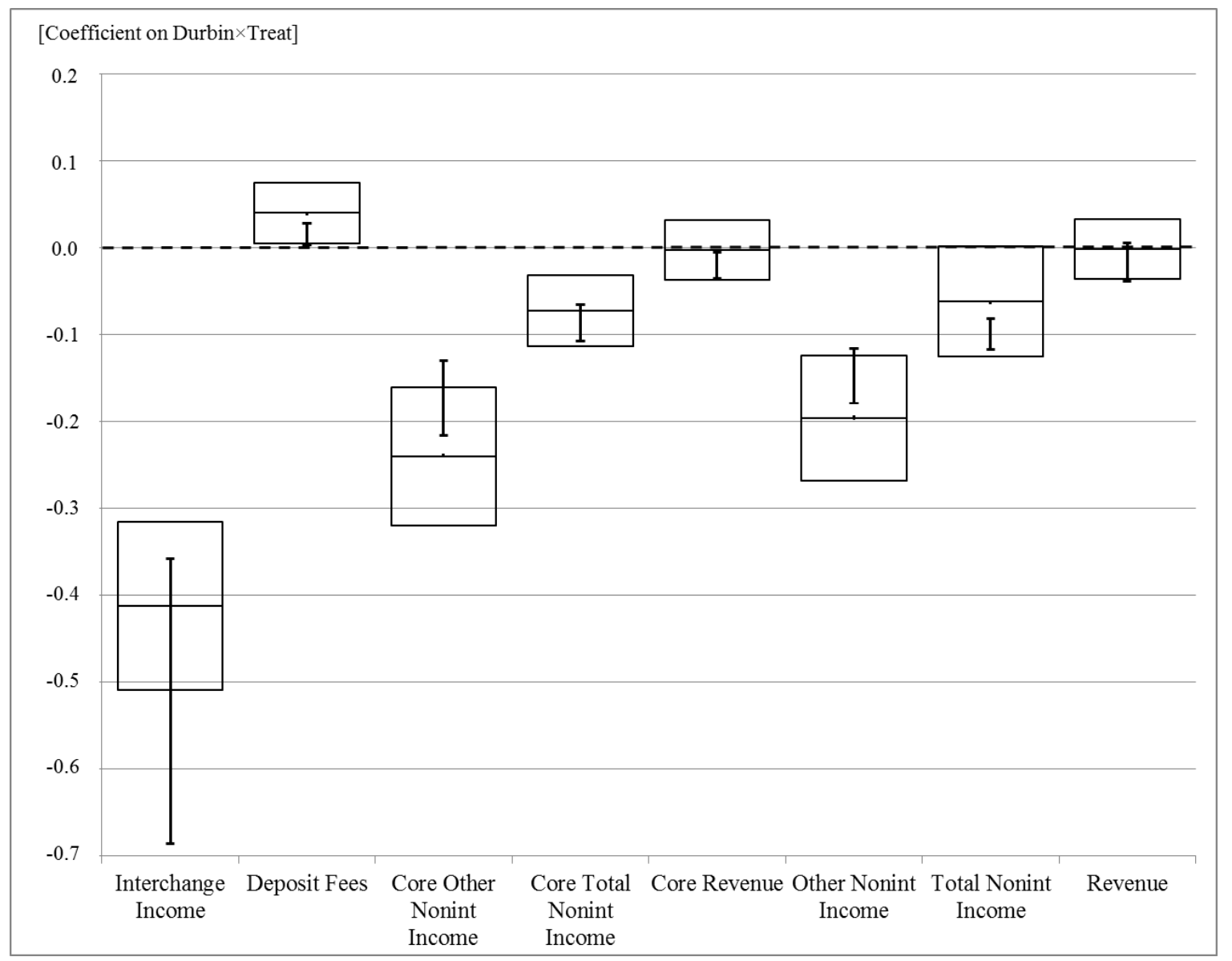

Note: The $y$-axis is the point estimate of the coefficient on the interacted term (Durbin $\times$ Treated). The range of point estimates for a coefficient based on running thirty-six different asset size regressions is designated by the vertical line. The minimum asset size ranges from $\$ 3$ billion to $\$ 8$ billion (by intervals of $\$ 1$ billion), and the maximum asset size ranges from $\$ 15$ billion to $\$ 40$ billion (by intervals of $\$ 5$ billion). The original estimate is designated by the middle horizontal line in the box. The box outline shows statistical significance at the 5 percent level for the original estimate.

To address this concern, we rerun the regressions shown above but confine analysis to banks in the Consistent Panel with asset sizes close to the $\$ 10$ billion threshold. Thirty-six asset groups are tested using a minimum asset size ranging from $\$ 3$ billion to $\$ 8$ billion (by intervals of $\$ 1$ billion) and a maximum asset size ranging from $\$ 15$ billion to $\$ 40$ billion (by intervals of $\$ 5$ billion). Asset groups are established using total assets as of December 31, 2010. Given that there are few banks around the $\$ 10$ billion threshold, the resulting sample sizes fall significantly, ranging from 25 to 101 firms.

Figure 2 summarizes the point estimates of these regressions. The ranges of the sensitivity 
analysis is designated by the vertical lines. The boxes represent the original estimate and statistical significance at the 5 percent level. Despite the limited number of firms, the primary results hold. Interchange income declines for treated firms. The upper bound is a 30 percent drop $(\exp (-0.358)-1=-0.301)$. Core total noninterest income also declines. Point estimates range from a 6 to 10 percent decrease. If only statistically significant results at the 5 percent level are considered, the range is a 7 to 10 percent decrease. The sign of the point estimate for the revenue regression is consistently negative across asset groups, ranging from a 0 to 3 percent decline, but none are statistically different from zero. The sign of the point estimate for the deposit fees regression is consistently positive, but again the results are not statistically different from zero. However, given the reduction in sample size, a large loss in power is to be expected. We fail to reject that the restricted and full sample estimates are the same. The fact that the estimated coefficient on deposit fees is lower for these smaller asset groups is also consistent with the largest banks having more market power to raise fees.

\section{Annual Data}

As mentioned in the data section, income statement items are reported year-to-date (YTD) and are censored and contain measurement error. In an attempt to ensure these issues are not driving our results, we run the same tests using year-to-date income and expense values (again on the full sample of firm sizes) for the fourth quarter, effectively annual data. Table 11 reports these income results 26

An important caveat here is that since 2011 contains only a single treated quarter while 2012 contains three, the estimates of the 2011 effects should be roughly tripled to compare with 2012 effects. To help capture this, Treat $\times y 2011=1$ for treated firms, and Treat $\times y 2012=3$. Adjusting for the number of quarters to get an annual growth rate again we find a significant change of approximately 40 percent decrease in interchange income. The coefficients on the interacted terms in the deposit fees regressions are not statistically different from zero and have mixed signs. However, core other noninterest income broadly confirms the previous results with reductions of approximately 25 percent. Core total noninterest income also declines by approximately 5 percent. There is

\footnotetext{
${ }^{26}$ Recall that YTD panels are defined separately from those used above. The Consistent Panel requires annual data for at least the time period 2010-2012 for all dependent variables. The individual variable panels require annual data for at least 2010-2012 for the given dependent variable in the regression.
} 
still insufficient power to detect changes in revenue.

The coefficients on the expense regressions continue to be positive but generally have no statistical significance. For space considerations, these results are not reported.

Table 11: Year-to-Date Income Regressions

\begin{tabular}{|c|c|c|c|c|c|c|c|c|c|c|}
\hline \multirow[b]{2}{*}{ Variables } & \multicolumn{2}{|c|}{$\begin{array}{l}\text { Interchange } \\
\text { Income }\end{array}$} & \multicolumn{2}{|c|}{$\begin{array}{l}\text { Deposit } \\
\text { Fees }\end{array}$} & \multicolumn{2}{|c|}{$\begin{array}{c}\text { Core Other } \\
\text { Noninterest Income } \\
\text { Core Oth }\end{array}$} & \multicolumn{2}{|c|}{$\begin{array}{c}\text { Core Total } \\
\text { Noninterest Income } \\
\text { Core Tot }\end{array}$} & \multicolumn{2}{|c|}{$\begin{array}{c}\text { Core } \\
\text { Revenue } \\
\end{array}$} \\
\hline & $\begin{array}{c}\text { Consistent } \\
1\end{array}$ & $\begin{array}{c}\text { Interchange } \\
2\end{array}$ & $\begin{array}{c}\text { Consistent } \\
3\end{array}$ & $4^{\text {Fees }}$ & $\begin{array}{c}\text { Consistent } \\
5\end{array}$ & $\begin{array}{c}\text { Nonint Inc } \\
6\end{array}$ & $\begin{array}{c}\text { Consistent } \\
7\end{array}$ & $\begin{array}{c}\text { Nonint Inc } \\
8\end{array}$ & $\begin{array}{c}\text { Consistent } \\
9\end{array}$ & $\begin{array}{l}\text { Revenue } \\
10\end{array}$ \\
\hline Treat×y2011 & $\begin{array}{r}-0.185^{* * *} \\
(0.0468)\end{array}$ & $\begin{array}{r}-0.168^{* * *} \\
(0.0496)\end{array}$ & $\begin{array}{l}-0.0100 \\
(0.0203)\end{array}$ & $\begin{array}{r}-0.0183 \\
(0.0226)\end{array}$ & $\begin{array}{r}-0.111^{* *} \\
(0.0465)\end{array}$ & $\begin{array}{r}-0.0970^{* *} \\
(0.0449)\end{array}$ & $\begin{array}{r}-0.0568^{* *} \\
(0.0262)\end{array}$ & $\begin{array}{r}-0.0598^{*} \\
(0.0355)\end{array}$ & $\begin{array}{r}-0.0155 \\
(0.0251)\end{array}$ & $\begin{array}{r}-0.00296 \\
(0.0271)\end{array}$ \\
\hline Treat×y2012 & $\begin{array}{r}-0.103^{* * *} \\
(0.0139)\end{array}$ & $\begin{array}{r}-0.105^{* * *} \\
(0.0151)\end{array}$ & $\begin{array}{r}0.00865 \\
(0.00542)\end{array}$ & $\begin{array}{r}0.00629 \\
(0.00476)\end{array}$ & $\begin{array}{r}-0.0648^{* * * *} \\
(0.00991)\end{array}$ & $\begin{array}{r}-0.0704^{* * * *} \\
(0.0127)\end{array}$ & $\begin{array}{l}-0.0132^{* *} \\
(0.00554)\end{array}$ & $\begin{array}{l}-0.0103^{* *} \\
(0.00520)\end{array}$ & $\begin{array}{r}0.00235 \\
(0.00340)\end{array}$ & $\begin{array}{r}-0.0207 \\
(0.0215)\end{array}$ \\
\hline Constant & $\begin{array}{r}0.141^{* * *} \\
(0.0204)\end{array}$ & $\begin{array}{r}0.144^{* * *} \\
(0.0203)\end{array}$ & $\begin{array}{r}0.00524 \\
(0.00747)\end{array}$ & $\begin{array}{r}0.00688 \\
(0.00761)\end{array}$ & $\begin{array}{r}0.123^{* * *} \\
(0.0153)\end{array}$ & $\begin{array}{r}0.121^{* * *} \\
(0.0142)\end{array}$ & $\begin{array}{r}0.0151^{*} \\
(0.00915)\end{array}$ & $\begin{array}{r}0.0248^{* * *} \\
(0.00909)\end{array}$ & $\begin{array}{r}0.0359^{* * *} \\
(0.00515)\end{array}$ & $\begin{array}{r}0.0414^{* * *} \\
(0.00591)\end{array}$ \\
\hline Observations & 2,225 & 2,261 & 2,361 & 3,523 & 2,334 & 3,303 & 2,361 & 3,600 & 2,361 & 3,615 \\
\hline Firms & 616 & 626 & 616 & 930 & 616 & 887 & 616 & 953 & 616 & 956 \\
\hline R-squared & 0.031 & 0.031 & 0.023 & 0.008 & 0.036 & 0.015 & 0.004 & 0.002 & 0.009 & 0.010 \\
\hline Adj. R-squared & 0.029 & 0.029 & 0.021 & 0.006 & 0.034 & 0.014 & 0.002 & 0.000 & 0.007 & 0.009 \\
\hline
\end{tabular}

\subsection{Balance Sheet Reaction}

In this section, we examine the possibility that firms managed their assets in recognition of the $\$ 10$ billion threshold that determines a firm's status under the Durbin Amendment. To avoid the interchange fee restrictions, firms just above the threshold may have an incentive to shrink their assets to get below it, whereas firms just below the threshold may have an incentive to limit their growth to avoid crossing it. If the benefits of avoiding the interchange fee restrictions outweigh any costs of adjusting assets, this behavior would be a natural response to the threshold. In addition to further illustrating the significance of the interchange fee restrictions, evidence of asset management would provide an interesting example of efforts to avoid differential regulation based on this type of threshold. However, the absence of this sort of behavior is important for the identification strategy we employ in our other analyses. If firms adjusted their assets to affect their status under the Durbin Amendment, then the assumption that treatment was exogenous from the perspective of the firms would be in doubt.

To investigate this issue, we first consider whether patterns of transitions from below the 
Table 12: Probability of Nominal Assets Exceeding $\$ 10$ billion at Year-End

\begin{tabular}{llcccc}
\hline & & \multicolumn{4}{c}{ Range of Nominal Asset Values at } \\
& & Previous Year-End (\$ in Billions) \\
& & $<5)$ & {$[\mathbf{5 , 1 0})$} & {$[\mathbf{1 0 , 1 5})$} & $\geq \mathbf{1 5}$ \\
Year & & 1 & 2 & 3 & 4 \\
\hline & & & & \\
2009 & Prob $\geq 10 \mathrm{~B}$ & 0.000 & 0.083 & 1.000 & 1.000 \\
& $\mathrm{~N}$ & 505 & 36 & 12 & 36 \\
2010 & Prob $\geq 10 \mathrm{~B}$ & 0.000 & 0.057 & 0.800 & 1.000 \\
& $\mathrm{~N}$ & 536 & 35 & 15 & 37 \\
2011 & Prob $\geq 10 \mathrm{~B}$ & 0.000 & 0.053 & 0.923 & 1.000 \\
& $\mathrm{~N}$ & 576 & 38 & 13 & 39 \\
2012 & Prob $\geq 10 \mathrm{~B}$ & 0.000 & 0.054 & 1.000 & 1.000 \\
& $\mathrm{~N}$ & 574 & 37 & 13 & 40 \\
\hline
\end{tabular}

Note: The first entry $(\mathrm{P}>10 \mathrm{~B})$ for each year (rows) provides the empirical frequency that firms have nominal assets in excess of $\$ 10$ billion at the end of that year conditional on having nominal assets in a particular range (columns) at the end of the previous calendar year. The second entry $(\mathrm{N})$ provides the number of firms with nominal assets in the relevant range at the end of the previous calendar year. This analysis uses the Consistent Panel.

$\$ 10$ billion threshold to above it, or vice versa, changed over time ${ }^{27}$ In particular, for 2009 through 2012, table 12 shows the empirical probability of exceeding the threshold at the end of a year conditional on having assets in a certain range at the end of the previous year, i.e.,

$$
P\left(A_{i, t} \geq 10 \mid A_{i, t-1} \in A\right),
$$

where $A_{i, t}$ is firm $i$ 's nominal assets at time $t{ }^{28}$ The second entry reports the number of firms in that asset range at the end of the previous year. For example, 36 firms in our data had nominal assets between $\$ 5$ billion and $\$ 10$ billion at the end of 2008 of which 3 grew above $\$ 10$ billion by the end of 2009 , yielding an estimated probability of 0.083 for that group. ${ }^{29}$

Table 12 documents three key results. First, the threshold is only relevant for firms in a relatively narrow range of assets around $\$ 10$ billion. No firms below $\$ 5$ billion grew above

\footnotetext{
${ }^{27}$ In addition to the non-parametric analysis presented here, we also considered parametric models in which we used probit models, for example, to estimate the probability of assets in excess of $\$ 10$ billion conditional on previous year-end assets. That analysis yielded similar conclusions to those in tables 12 and 13 .

${ }^{28}$ The asset size exemption in the Durbin Amendment is not adjusted for inflation. Our results are largely unchanged if we consider real asset growth relative to the nominal threshold to remove growth due to inflation.

${ }^{29}$ Throughout this section, we use fourth quarter data from the Consistent Panel for 2008 to 2012 , although our findings are robust to alternative samples from the data.
} 
the threshold during the time period that we consider, and no firms above $\$ 15$ billion shrank below it. Second, for firms in the range of $\$ 5$ billion to $\$ 15$ billion, transitions above or below the threshold are relatively rare events. Finally, and most importantly for our overall analysis, if we take year-end 2011 as the first post-amendment date, we see little evidence that firms with assets between $\$ 5$ billion and $\$ 10$ billion were less likely to grow above $\$ 10$ billion and no evidence that firms with assets between $\$ 10$ billion and $\$ 15$ billion became more likely to fall below the threshold 30

The analysis in table 12 examines the exact criterion for a bank's status under the interchange fee restrictions and, therefore, directly addresses the concern over firm treatment endogeneity. However, the lack of any change in the probability of crossing the threshold is necessary but arguably not sufficient to demonstrate the absence of any response. Asset growth may have adjusted in response to the amendment without altering the probabilities in table 12 given the rare nature of the underlying event. Moreover, any conclusions that we might draw about asset growth based on the threshold analysis are complicated by the fact that we cannot distinguish the effects of the Durbin Amendment from other broad factors, such as overall macroeconomic and financial conditions.

To address these concerns, we examine features of the distribution of asset growth by looking at realized growth for firms in different asset ranges around $\$ 10$ billion. Specifically, using data for 2009 to 2012, we consider a regression of the form

$$
\ln \left(A_{i, t}\right)-\ln \left(A_{i, t-1}\right)=\alpha_{t}+\beta_{1 t} d_{1 i, t}+\beta_{2 t} d_{2 i, t}+\varepsilon_{i, t},
$$

where $d_{1 i, t}=1$ if $A_{i, t-1} \in[5 B, 10 B)$ and $d_{2 i, t}=1$ if $A_{i, t-1} \in[10 B, 15 B)$. By considering the growth of firms at different distances from the threshold, this analysis arguably allows us to compare the experience over time of firms for which the threshold was relevant to those for which it was not in order to isolate the potential effects of the Durbin 
Table 13: Estimates of Mean Growth in Nominal Assets

\begin{tabular}{|c|c|c|c|c|}
\hline & & $\begin{array}{c}\text { Range of } \\
\text { Previous } \\
{[5,10)}\end{array}$ & $\begin{array}{c}\text { Nominal Asset } \\
\text { Year-End }(\$ \text { in } \\
\qquad 10,15)\end{array}$ & $\begin{array}{c}\text { Values at } \\
\text { Billions) } \\
\text { All }\end{array}$ \\
\hline 2009 & $\begin{array}{l}\text { Mean } \\
\text { SE }\end{array}$ & $\begin{array}{c}0.008 \\
(0.023)\end{array}$ & $\begin{array}{c}0.007 \\
(0.049)\end{array}$ & $\begin{array}{c}0.040 \\
(0.004)\end{array}$ \\
\hline 2010 & $\begin{array}{l}\text { Mean } \\
\text { SE }\end{array}$ & $\begin{array}{l}-0.030 \\
(0.028)\end{array}$ & $\begin{array}{l}-0.004 \\
(0.041)\end{array}$ & $\begin{array}{c}0.013 \\
(0.004)\end{array}$ \\
\hline 2011 & $\begin{array}{l}\text { Mean } \\
\text { SE }\end{array}$ & $\begin{array}{c}0.023 \\
(0.027)\end{array}$ & $\begin{array}{c}0.027 \\
(0.023)\end{array}$ & $\begin{array}{c}0.023 \\
(0.007)\end{array}$ \\
\hline 2012 & $\begin{array}{l}\text { Mean } \\
\text { SE }\end{array}$ & $\begin{array}{c}0.016 \\
(0.016)\end{array}$ & $\begin{array}{c}0.038 \\
(0.017)\end{array}$ & $\begin{array}{c}0.041 \\
(0.004)\end{array}$ \\
\hline
\end{tabular}

Note: Growth is measured as log differences of year-end assets from $t-1$ to $t$. The entries for each year (rows) provides the sample mean and standard error (SE) of asset growth for firms having nominal assets in a particular range (columns) at the end of the previous calendar year. These estimates are generated by regressing log differences on year and asset size dummy variables. R-squared value is 0.070 .

Amendment 31

Table 13 presents the results of this regression and illustrates a number of findings. First, we see a substantial decline in growth from 2009 to 2010, both for firms as a whole and particularly for firms in the two ranges around $\$ 10$ billion. Notice that the latter effects are generally far from statistically significant. Average growth then recovered substantially in 2011 and 2012 for firms overall. Second, we do not see any significant differences across groups or over time within a group that are indicative of a Durbin Amendment effect. For example, growth in 2011 for firms with assets between $\$ 5$ billion and $\$ 10$ billion was higher than growth for firms as a whole and, more importantly, was higher than growth for analogous firms in 2010. We obtain similar results for firms with assets between $\$ 10$ billion and $\$ 15$ billion. Although these differences are generally statistically insignificant, their signs are not consistent with firms near the threshold slowing their asset growth to avoid crossing it or shrinking their assets to avoid it.

\footnotetext{
${ }^{30}$ Recall that the interchange fee restrictions became effective in the fourth quarter of 2011. A firm's status in that quarter was based on its assets as of year-end 2010. However, firms were unlikely to anticipate that their 2010 assets would govern their exempt status in 2011:Q4, as this relationship was not specified in the Durbin Amendment, but was established when the implementing regulation was finalized in mid-2011. As a result, year-end 2011 is arguably the first date at which firms might consider their assets relative to the amendment's threshold.

${ }^{31}$ We also considered non-parametric kernel estimators to allow even more flexibility in growth around the threshold. That analysis yielded similar conclusions to those in table 13.
} 
The results in tables 12 and 13 provide no evidence that firms have engaged in significant management of their assets to affect their status under the Durbin Amendment. To the extent that banks continue to grow over time, the threshold in the amendment will become relevant for an increasing number of firms. As this occurs, it will be interesting to revisit and extend this analysis to examine whether firms appear to respond to this regulatory threshold.

\section{Conclusion}

In aggregate, we estimate Reg II was poised to reduce income at large banks by nearly $\$ 14$ billion a year or more than 5 percent of core total noninterest income. As multiproduct oligopolists, banks had multiple margins on which to ameliorate this effect: raising revenue on other products, reducing the quality of related services, and strategically altering their balance sheets to avoid being treated by the law. Indeed, they said so. During the fourth quarter 2011 earnings conference call for Fifth Third Bank, the CFO made the following comment with regard to interchange fee regulation:

We have a multi-pronged mitigation approach that would include such actions as reducing the cost associated with debt card offers, changes and eliminations to rewards, selected fees, incorporation of debit usage in the bundled deposit product offerings, and the implementation of new products. We are consulting with our customers about their preferences for our services and how they pay for those services. (Source: FactSet CallStreet and provided by SNL Financial. The conference call was on January 20, 2012.)

In practice, raising revenue on other products was important, but the other margins were not. Banks were able to offset approximately 30 percent of lost interchange revenue with higher fees on deposit services. Assessing the effect of Reg II on higher level income measures allows us to reject full mitigation of the law up to the level of core total noninterest income. Mitigation consistent with the observed higher deposit fees cannot be rejected. Bank expenses like salaries, premises, and noninterest expenses do not diminish 
in response to the law. The number of branches and bank headcount also do not decline. As measured by changes in balance sheets, banks are neither less likely to grow to above $\$ 10$ billion in assets the law uses as a threshold, nor do banks below the threshold grow more slowly.

We find that these results are robust to numerous variations in the composition of the panel. Both panel families give similar results. Restricted subsamples focusing on banks near the $\$ 10$ billion threshold also give similar results. Finally, using yearly rather than quarterly data to reduce selection by infrequent reporters of interchange income also gives similar results.

Along the way we observe several additional interesting responses by the banks. In the face of the partial revenue loss mitigation, we find that banks continued to grow their debit card transactions and the number of their accounts. Given the much lower revenue per debit transaction and the significant contribution of interchange income to overall noninterest income both would likely have declined in a perfectly competitive setting. In light of this positive quantity response to the introduction of a price ceiling and the substantial mitigation from price changes in related products, we conclude that the treated banks must have substantial oligopoly power.

\section{References}

Agarwal, S., S. Chomsisengphet, N. Mahoney, and J. Stroebel (2014). Regulating consumer financial products: evidence form credit cards. Working Paper, http: //papers.ssrn.com/sol3/papers.cfm?abstract_id=2330942.

American Bankers Association, Credit Union National Association, The Clearing House, Consumer Bankers Association, The Financial Services Roundtable, Independent Community Bankers of America, Mid-size Bank Coalition of America, National Association of Federal Credit Unions, and National Bankers Association (2011). Comment Letter, Februrary 22, www.federalreserve.gov/SECRS/2011/March/20110303/ $\mathrm{R}--1404 / \mathrm{R}--1404 \_022211$ _67218_584088138933_1.pdf

Baxter, W. F. (1983). Bank interchange of transactional paper: Legal and economic perspectives. Journal of Law and Economics 26(3), 541-588.

Bedre-Defolie, O. and E. Calvano (2013). Pricing payment cards. American Economic Journal: Microeconomics 5(3), 206-231. 
Claessens, S. and L. Laeven (2004). What drives bank competition? Some international evidence. Journal of Money, Credit and Banking 36(3, Part 2: Bank Concentration and Competition: An Evolution in the Making A Conference Sponsored by the Federal Reserve Bank of Cleveland May 21-23, 2003), 563-583.

Comptroller of the Currency (2001). Merchant Processing: Comptroller's Handbook (December ed.).

DeGennaro, R. P. (2006). Merchant acquirers and payment card processors: A look inside the black box. Economic Review (First Quarter), 27-42.

Evans, D. S. and R. Schmalensee (2004). Paying with Plastic: The Digital Revolution in Buying and Borrowing (2 ed.). Cambridge, MA: MIT Press.

Farnam, T. (2011). Lobbying efforts persist long after health-care, financial regulation bill passes. The Washington Post, April 23, http://wapo.st/g6uk0a.

Federal Reserve Board (2010). Reg II Proposal, December 16, www.federalreserve. gov/newsevents/press/bcreg/20101216a.htm.

Federal Reserve Board (2011a). Final Reg II, June 29, www.federalreserve.gov/ newsevents/press/bcreg/20110629a.htm.

Federal Reserve Board (2011b). 2009 interchange revenue, covered issuer cost, and covered issuer and merchant fraud loss related to debit card transactions. Federal Reserve Board Paper, June, www.federalreserve.gov/paymentsystems/files/debitfees_costs. pdf.

Federal Reserve Board (2013). 2011 interchange fee revenue, covered issuer costs, and covered issuer and merchant fraud losses related to debit card transactions. Federal Reserve Board Paper, March 5, www.federalreserve.gov/paymentsystems/files/ debitfees_costs_2011.pdf.

Federal Reserve System (2011). The 2010 federal reserve payments study: Noncash payment trends in the united states 2006-2009. Federal Reserve System Paper, updated April 5, 2011, www.frbservices.org/files/communications/pdf/press/ 2010_payments_study.pdf.

Frankel, A. S. (2007). The reserve bank of australia's review of payment system reforms: Comments of alan s. frankel. Reserve Bank of Australia, www.rba.gov.au/payments--system/reforms/review--card--reforms/ pdf/frankel--31082007.pdf.

Genakos, C. and T. Valletti (2011). Testing the "waterbed" effect in mobile telephony. Journal of the European Economic Association 9(6), 1114-1142.

Gerdes, G. R. and J. K. I. Walton (2002). The use of checks and other noncash payment instruments in the united states. Federal Reserve Bulletin (August), 360-374.

Government Printing Office (2010). Dodd-Frank Wall Street Reform and Consumer Protection Act, July 21, www.gpo.gov/fdsys/pkg/PLAW--111publ203/pdf/ PLAW--111publ203.pdf. 
Hayashi, F. (2012). The new debit card regulations: Initial effects on networks and banks. Economic Review (Fourth Quarter), 79-115.

Hayashi, F. (2013). The new debit card regulations: Effects on merchants, consumers, and payments system efficiency. Economic Review (First Quarter), 89-118.

Hayashi, F., R. J. Sullivan, and S. E. Weiner (2006). A guide to the atm and debit card industry: 2006 update. Federal Reserve Bank of Kansas City, www.kc.frb.org/ publicat/psr/BksJournArticles/ATMDebitupdate.pdf.

Katz, M. L. (2001). Reform of credit card schemes in australia ii. Reserve Bank of Australia, ww--ho.rba.gov.au/payments--system/reforms/cc--schemes/ ii--commissioned--report/ii--commissioned--report.pdf.

Mui, Y. Q. (2011). Retailers fight back over debit-card swipe fees. The Washington Post, May 18, http://wapo.st/mwtPTl.

Mui, Y. Q. and C. Podkul (2011). Banks bid to delay debit card swipe-fee rules fails as senate vote falls short. The Washington Post, June 8, http://wapo.st/kLohFY.

National Retail Federation (2011). Comment Letter, Februrary 22, www. federalreserve.gov/SECRS/2011/March/20110301/R--1404/R--1404_022211_ 67821_571449248559_1.pdf.

Prager, R. A., M. D. Manuszak, E. K. Kiser, and R. Borzekowski (2009). Interchange fees and payment card networks: Economics, industry developments, and policy issues. Finance and Economics Discussion Series, 2009-23.

Rochet, J.-C. and J. Tirole (2002). Cooperation among competitors: Some economics of payment card associations. The RAND Journal of Economics 33(4), 549-570.

Rysman, M. and J. Wright (2012). The economics of payment cards. Working Paper, November 29, http://papers.ssrn.com/sol3/papers.cfm?abstract_id=2183420.

Schuh, S. and J. Stavins (2011). How consumer pay: Adoption and use of payments. Federal Reserve Bank of Boston Working Paper, 12-2.

Shaffer, S. (1989). Competition in the U.S. banking industry. Economics Letters 29(4), $321-323$.

Sullivan, R. J. (2013). The impact of debit card regulation on checking account fees. Economic Review (Fourth Quarter), 5-39.

Verdier, M. (2011). Interchange fees in payment card systems: A survey of the literature. Journal of Economic Surveys 25(2), 273-297.

Wildfang, K. C. and R. W. Marth (2006). The persistence of antitrust controversy and litigation in credit card networks. Antitrust Law Journal 73(3), 675-707. 


\section{A Details on Reg II and the Durbin Amendment}

The statute instructed the Board to issue final regulations related to the interchange fee restrictions within nine months of the passage of the Dodd-Frank Act, with an effective date of July 21, 2011. Figure 3 shows a timeline of major events related to the interchange fee regulation and, more broadly, the Dodd-Frank Act and the Durbin Amendment. In line with standard practice, the Board issued a proposed interpretation of the statute on December 16, 2010 and invited public comment. That interpretation contained two proposals for interchange fee restrictions. The first permitted a covered issuer to receive an interchange fee equal to its allowable per-transaction costs up to a cap of 12 cents per transaction with a "safe harbor" of 7 cents per transaction and the second specified a cap of 12 cents per transaction for all covered issuers.

Figure 3: Timeline of Major Durbin Amendment Events

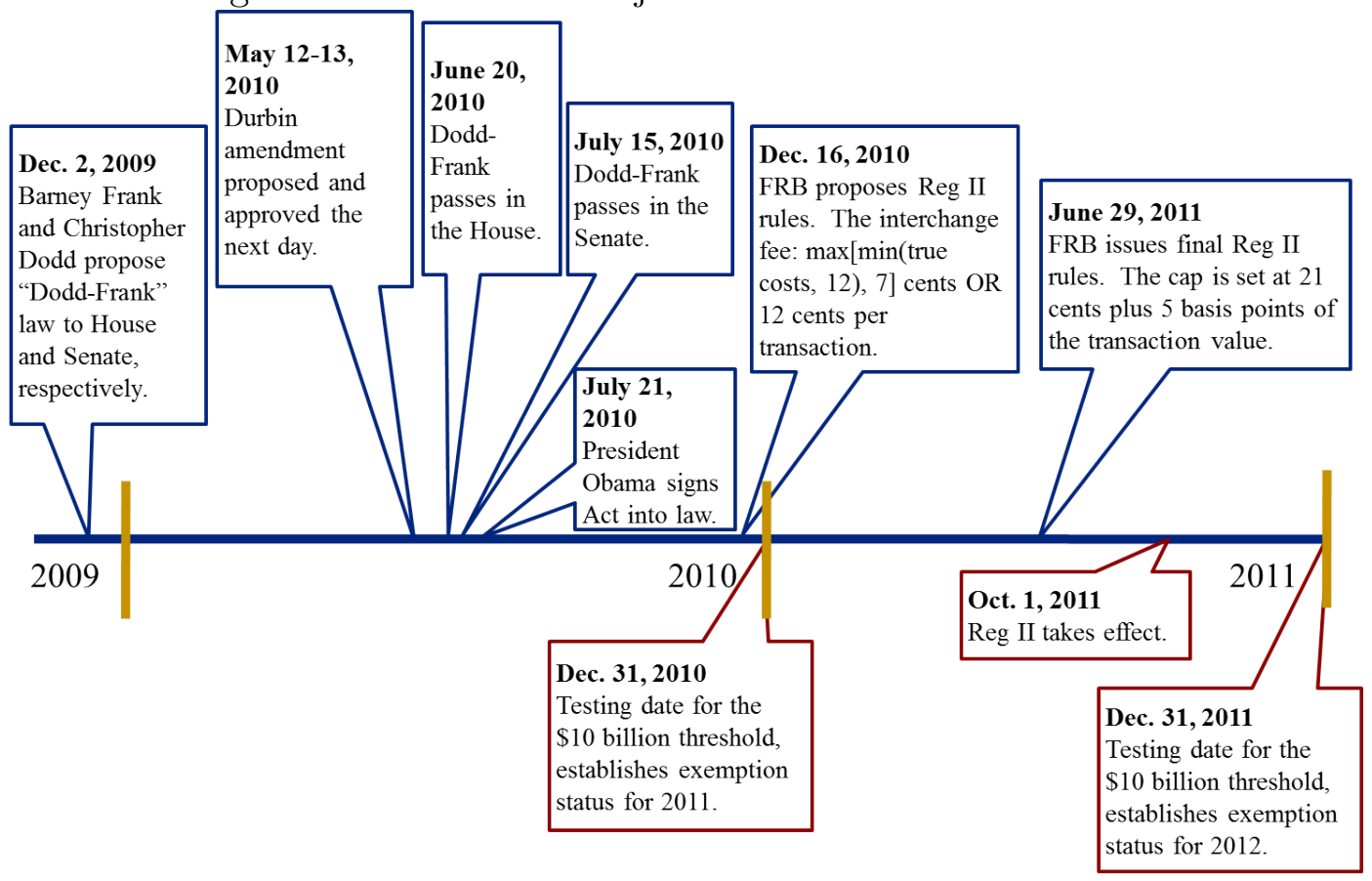

Following a period of robust public comment, during which interested parties submitted a large number of comments on the proposal (Mui 2011) and opponents of the amendment failed to delay it through congressional action (Farnam 2011; Mui and Podkul 2011), the Board issued Reg II on June 29, 2011, which codified the final rules concerning the Durbin Amendment. In recognition of delays in the rule-writing process and the need to provide industry participants with time to comply, the regulation altered the effective dates for various provisions in the Durbin Amendment and specifically established October 1, 2011 (2011:Q4) as the effective date for the restrictions on interchange fees.

With respect to those restrictions, Reg II includes a single cap equal to 21 cents per 
transaction applicable to all covered issuers ${ }^{32}$ Moreover, in recognition of the risk of fraud losses faced by an issuer, the interchange cap also permits covered issuers to receive up to 0.05 percent of the transaction value through interchange fees. Finally, as authorized by the Durbin Amendment, the regulation allows covered issuers to receive up to 1 cent per transaction for fraud-prevention costs provided an issuer meets the fraud-prevention standards established by the Board 33

\section{B Data Appendix}

\section{B.1 Construction of Testing Panels}

As described in section 3, we collect data from a variety of sources, which we then combine to yield a series of panel data sets. Our first data source, commonly known as the Y9C based on the title of the associated reporting form, is the Consolidated Financial Statements for Holding Companies, which are regulatory data reported quarterly by BHCs with assets of $\$ 500$ million or more. From these reports, we collect the income and expense items listed in schedule HI. Notably, these variables are related hierarchically. For example, interchange income is a component of other noninterest income along with items that we do not examine, such as safe deposit rent. Other noninterest income is, in turn, a component of noninterest income, as are deposit fees, another variable in our data. Tables 14 and 15 provide more detail about the relationship between variables in the Y-9C filings and the variables used in regressions (bolded).

As noted in the text, we collect bank-level data from two sources. First, we obtain information about the number of deposit accounts and full time equivalent employees for an institution from the quarterly Consolidated Reports of Condition and Income (Call Report) filed by commercial banks. Second, we collect annual counts of bank branches from the SOD published by the FDIC as of the end of the second quarter of each year. We aggregate these bank-level variables to the level of the topholder BHC. To do so, we use ownership and institutional information collected by the Federal Reserve System to

\footnotetext{
${ }^{32}$ The higher value in the final regulation reflects a somewhat broader definition of allowable costs than were considered in the original proposal. The numerical values for interchange fees in both the proposed and final regulation were based on information about debit card transaction costs that the Board collected through a survey of covered issuers in the fall of 2010. The survey instrument and a summary of the findings are available at wWw.federalreserve.gov/paymentsystems/regii-data-collections.htm.

${ }^{33}$ The Durbin Amendment required the Board to establish fraud prevention standards for debit card transactions, and issuers meeting those standards would be eligible to receive an additional fee to offset their costs of compliance.
} 
Table 14: Income \& Core Income Items (Schedule HI/RI item numbers*)

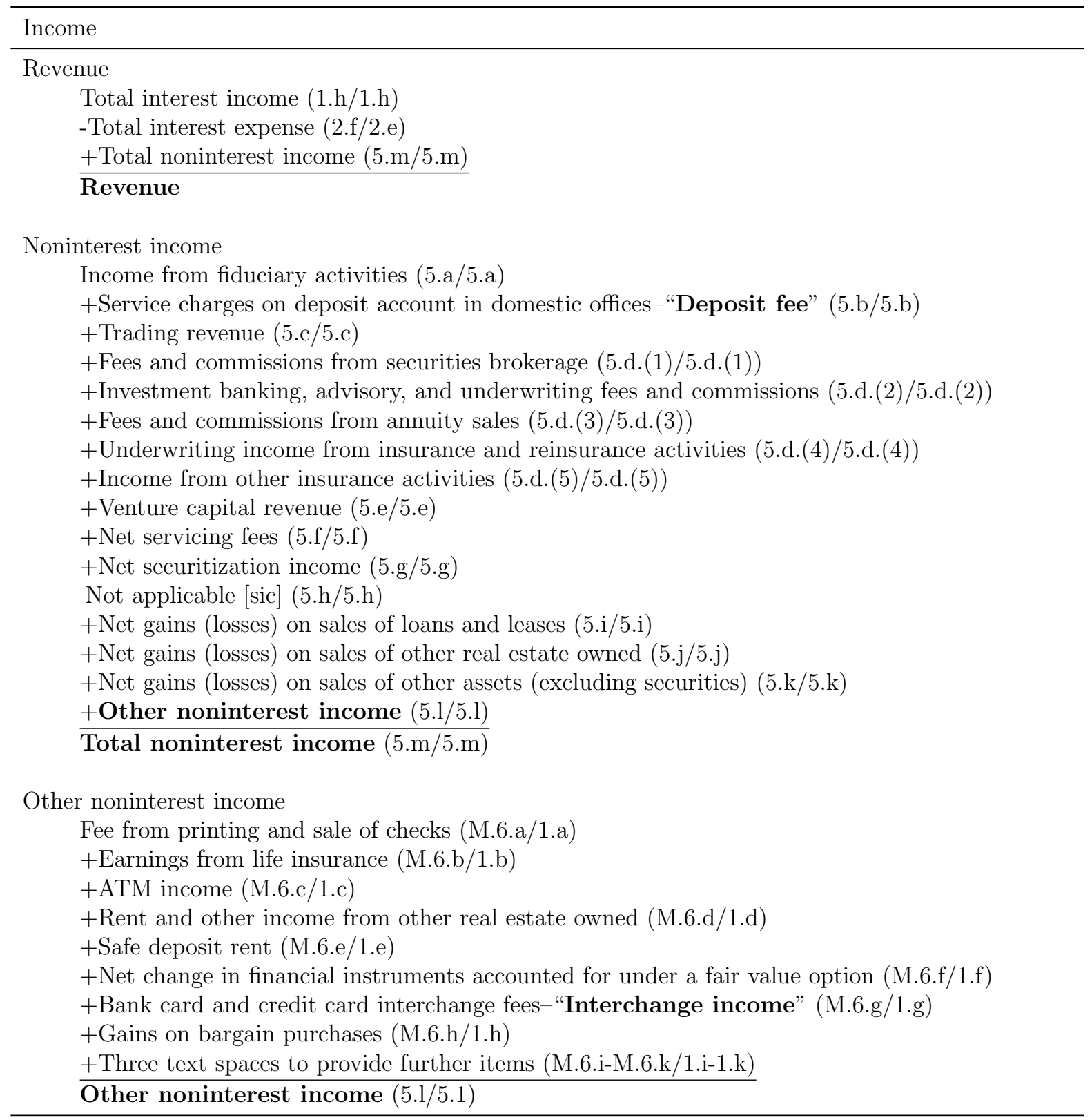

Core Income Definitions (using Y-9C items)

Core other noninterest income $=$ M.6. $a+$ M.6.b + M.6.c + M.6.d + M.6.e + M.6.g

Core total noninterest income $=5 \cdot \mathrm{a}+5 \cdot \mathrm{b}+5 \cdot \mathrm{d} \cdot(1-5)+5 \cdot \mathrm{e}+5 \cdot \mathrm{f}+5 \cdot \mathrm{g}+$ Core other nonint inc

Core revenue $=$ Total interest income - Total interest expense + Core total nonint inc

* The HI schedule is part of the Y-9C, and the RI schedule is part of the Call Report. Items that are memorandum items ("M") in the Y-9C appear in schedule RI-E of the Call Report.

identify the topholder BHC for each bank 34 We then combine the bank-level data for all subsidiaries of a given topholder BHC. For example, the number of a BHC's branches reflects the number of total branches for its bank affiliates as reported in the SOD. We then merge the resulting BHC-level data with the data for topholder BHCs from the

34 Most of this relationship data is available through the National Information Center website at WwW.ffiec.gov/nicpubseb/nicweb/SearchForm.aspx. 
Table 15: Expense Items (Schedule HI/RI item numbers*)

\section{Expense}

Total noninterest expense

Salaries and employee benefits-"Salaries" (7.a/7.a)

+Expenses of premises and fixed assets-"Premises" (7.b/7.b)

+Goodwill impairment losses (7.c.(1)/7.c.(1))

+ Amortization expense and impairment losses for other intangible assets (7.c.(2)/7.c.(2))

+ Other noninterest expense (7.d/7.d)

Total noninterest expense (7.e/7.e)

Other noninterest expense

Data processing expenses (M.7.a/2.a)

+Advertising and marketing expenses (M.7.b/2.b)

+Directors' fees (M.7.c/2.c)

+ Printing, stationery, and supplies (M.7.d/2.d)

+Postage (M.7.e/2.e)

+ Legal fees and expenses (M.7.f/2.f)

+FDIC deposit insurance assessments (M.7.g/2.g)

+ Accounting and auditing expenses (M.7.h/2.h)

+Consulting and advisory expenses (M.7.i/2.i)

+ATM and interchange expenses-"Interchange Expense" (M.7.j/2.j)

+Telecommunications expenses (M.7.k/2.k)

+ Three text spaces to provide further items (M.7.1-M.7.n/2.1-2.n)

Other noninterest expense (7.d/7.d)

* The HI schedule is part of the Y-9C, and the RI schedule is part of the Call Report. Items that are memorandum items ("M") in the Y-9C appear in schedule RI-E of the Call Report. 
Y-9C.

To determine the exemption status of topholder BHCs, we obtain information about the exemption status of individual banks from the lists of exempt and non-exempt depository institutions that the Board has issued annually since 2011 35 Per the regulation, the lists base an institution's status for a given year on its consolidated year-end assets for the previous year. For example, an institution's status for 2011 reflects assets for itself and all of its affiliates from regulatory filings for December 31, 2010. The regulation allows firms that become newly non-exempt to come into compliance with the interchange restrictions by the third quarter of the year of the transition. The status variables that we use account for this lag. A topholder BHC then inherits the exempt or non-exempt status of its subsidiary banks from the lists ${ }^{36}$

We clean these data in several ways. First, for most of our analysis, we convert the yearto-date income statement items into quarterly data 37 Second, we adjust the data for mergers and acquisitions that occur during a year to avoid distortions to the quarterly data of a BHC that absorbs a purchased bank during the course of a year ${ }^{38}$ Finally, to clean up data errors, we exclude observations of income statement items that are negative ${ }^{39}$ Negative items are rare and generally occur with the same frequency across treated and not-treated BHCs. Occurrences of negatives are summarized in table 16.

Table 16: Occurrences of Negative Values, by Treatment Group

\begin{tabular}{|c|c|c|c|c|c|c|c|c|c|c|}
\hline & Interchange & $\begin{array}{r}\text { Deposit } \\
\text { Fee }\end{array}$ & $\begin{array}{l}\text { Other } \\
\text { Nonint } \\
\text { Income }\end{array}$ & $\begin{array}{r}\text { Total } \\
\text { Nonint } \\
\text { Income }\end{array}$ & Revenue & Salaries & Premises & $\begin{array}{r}\text { Other } \\
\text { Nonint } \\
\text { Expense }\end{array}$ & $\begin{array}{r}\text { Total } \\
\text { Nonint } \\
\text { Expense }\end{array}$ & $\begin{array}{l}\text { All } \\
\text { Obs }\end{array}$ \\
\hline \multicolumn{11}{|c|}{ Negative Observations } \\
\hline Treated Firms & 18 & 7 & 84 & 56 & 12 & 4 & 3 & 6 & 3 & 1,755 \\
\hline Not-Treated Firms & 209 & 17 & 306 & 699 & 33 & 7 & 9 & 23 & 8 & 18,509 \\
\hline All Firms & 227 & 24 & 390 & 755 & 45 & 11 & 12 & 29 & 11 & 20,264 \\
\hline \multicolumn{11}{|c|}{ Percent of Observations (by group) } \\
\hline Treated Firms & 1 & 0 & 5 & 3 & 1 & 0 & 0 & 0 & 0 & \\
\hline Not-Treated Firms & 1 & 0 & 2 & 4 & 0 & 0 & 0 & 0 & 0 & \\
\hline All Firms & 1 & 0 & 2 & 4 & 0 & 0 & 0 & 0 & 0 & \\
\hline
\end{tabular}

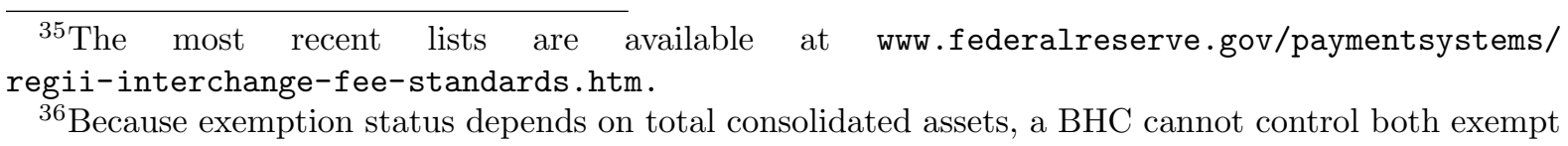
and non-exempt banks.

${ }^{37}$ As we discuss in more detail in section 3 we perform some analysis using annual data.

${ }^{38}$ Under reporting rules, the income statement items of a purchased bank for quarters prior to the completion of a merger are not included in the regulatory filings of the purchaser. Merger adjustment adds income statement flows for the target bank to those of the purchaser by using the target's financials from filings earlier in the year. Because income statement items are reported year-to-date, these adjustments are larger in later quarters.

${ }^{39}$ Note that expense items are reported as positive numbers. Negative numbers can occur due to true losses, reporting errors, restatement adjustments, or items that are not reported every quarter because a threshold is not met. 


\section{B.2 Reasons for Using Core Income Measures}

Table 17 reports the law's effect on aggregated measures of bank income that include core and non-core income. As reported in columns 1 and 2 of table 17 , other noninterest income is substantially reduced by the law, in the range of 15 to 18 percent $(\exp (-0.196)-1=$ -0.18 ; $\exp (-0.158)-1=-0.15)$. Because interchange income is about 37 percent of other noninterest income for treated firms in the Consistent Panel (table 5), the regression result actually implies that other noninterest income fell more than if interchange income fell as observed but everything else remained unchanged (18 percent $>0.34 \times 0.37=$ 12.6 percent).

Table 17: Broader Income Category Regressions

\begin{tabular}{|c|c|c|c|c|c|c|}
\hline \multirow[b]{2}{*}{ Variables } & \multicolumn{2}{|c|}{ Other Noninterest Inc } & \multicolumn{2}{|c|}{ Total Noninterest Inc } & \multicolumn{2}{|c|}{ Revenue } \\
\hline & $\begin{array}{c}\text { Consistent } \\
1\end{array}$ & $\begin{array}{c}\text { Oth Nonint Inc } \\
2\end{array}$ & $\begin{array}{c}\text { Consistent } \\
3 \\
\end{array}$ & $\begin{array}{c}\text { Tot Nonint Inc } \\
4\end{array}$ & $\begin{array}{c}\text { Consistent } \\
5\end{array}$ & $\begin{array}{c}\text { Revenue } \\
6\end{array}$ \\
\hline Durbin $\times$ Treat & $\begin{array}{r}-0.196^{* * *} \\
(0.0365)\end{array}$ & $\begin{array}{r}-0.158^{* * * *} \\
(0.0392)\end{array}$ & $\begin{array}{l}-0.0618^{*} \\
(0.0325)\end{array}$ & $\begin{array}{r}-0.107^{* * * *} \\
(0.0322)\end{array}$ & $\begin{array}{r}-0.00168 \\
(0.0176)\end{array}$ & $\begin{array}{r}-0.0383^{*} \\
(0.0222)\end{array}$ \\
\hline Constant & $\begin{array}{r}-0.00238 \\
(0.0215)\end{array}$ & $\begin{array}{r}-0.0188 \\
(0.0187)\end{array}$ & $\begin{array}{r}0.00993 \\
(0.0159)\end{array}$ & $\begin{array}{r}-0.00282 \\
(0.0148)\end{array}$ & $\begin{array}{r}0.0341^{* * * *} \\
(0.00781)\end{array}$ & $\begin{array}{l}0.0178^{* *} \\
(0.00812)\end{array}$ \\
\hline Observations & 11,174 & 16,371 & 10,904 & 15,529 & 11,415 & 17,024 \\
\hline Firms & 688 & 1,029 & 688 & 983 & 688 & 1,047 \\
\hline R-squared & 0.008 & 0.005 & 0.018 & 0.014 & 0.007 & 0.007 \\
\hline Adj. R-squared & 0.007 & 0.004 & 0.017 & 0.013 & 0.006 & 0.005 \\
\hline
\end{tabular}

Robust standard errors in parentheses are clustered at the firm level.

Year-quarter dummies are suppressed.

*** $\mathrm{p}<0.01,{ }^{* *} \mathrm{p}<0.05,{ }^{*} \mathrm{p}<0.10$

The estimated effect on total noninterest income is also negative and statistically significant. Using the point estimate, the effect is again more than expected based on the decrease in interchange income and the relative size of interchange income to total noninterest income $(6.2$ percent $>0.34 \times 0.15=5.1$ percent $)$, implying no mitigation at this level. In general, banks were unable to make broader income sources offset the Durbin Amendment, otherwise the effects from table 2 would be attenuated rather than amplified.

Finally, the revenue regression results also show a decrease for treated firms, but results are quantitatively low and only the one specification has weakly significant results. These results are sensible given that interchange income was only 4 percent of revenue for the Consistent Panel before the law (table 5).

It is somewhat puzzling that treatment effects on higher level income measures are too 
large relative to what we would expect. That is, in the absence of mitigation,

$$
\Delta \text { interchange } \times \frac{\text { interchange }}{\text { broader income }}=\Delta \text { broader income, }
$$

but instead we find that broader income falls roughly one-and-a-half times as much as we would expect. This anomaly is caused by the timing of one-time charge-offs from financial risk taking owing to decisions made significantly before debit card reform.

A review of the changes in the components (M.6.a-M.6.k) of other noninterest income (5.1) reveals several key findings 40 For the Consistent Panel, a majority (64 percent) of other noninterest income is not in the formal subcategories (M.6.a-M.6.g) ${ }^{41}$ This nonformal other noninterest income consists of two parts: 1) three free text fields (M.6.iM.6.k), amounting to 24 percent of other noninterest income and 2) a little-documented residual component that equals other noninterest income - sum(M.6.a-M.6.g,M.6.i-M.6.k), amounting to 40 percent of other noninterest income.

Examination of the three free text fields, especially for treated firms, reveals that there were large decreases in the values contemporaneous with the implementation of Reg II. Further, these large changes (losses) are associated with changes in the values of hedges, negative revaluations of FDIC loss share agreements, and other sources that appear to be realizations of pre-Durbin decisions and nonrecurring in nature. It is likely that the residual component is also made of similar extraordinary items. As a result of these, we use the core income measures for our primary analysis.

\section{B.3 Instructions for Other Noninterest Income and Expense}

The form instructions for other noninterest income state that banks are to

Include as other noninterest income.... (6) Charges to merchants for the banks handling of credit card or charge sales when the holding company does not carry the related loan accounts on its books. Holding companies may report this income net of the expenses (except salaries) related to the handling of these credit card sales 42

Similar language appears for other noninterest expense:

\footnotetext{
${ }^{40}$ These components are listed in table 14 in appendix $\mathrm{B}$

${ }^{41}$ Category M.6.h is excluded because this line item is only available beginning 2009:Q4.

${ }^{42}$ Y-9C instructions are available at www.federalreserve.gov/apps/reportforms/default.aspx
} 
(24) Expenses (except salaries) related to handling credit card or charge sales received from merchants when the holding company or its consolidated subsidiaries do not carry the related loan accounts on its books. Holding companies are also permitted to net these expenses against their charges to merchants for the holding companys handling of these sales reported in item 5(l) above.

These instructions allow banks to either report interchange income gross or net of related expenses.

\section{B.4 Instructions for Deposit Fees}

The deposit fee line item in regulatory financial statements includes a wide variety of fees. The language below comes from the reporting form instructions.

\section{Current Y-9C Instructions for Deposit Fees}

Line Item 5(b) Service charges on deposit accounts in domestic offices. Report in this item amounts charged depositors in domestic offices:

(1) For the maintenance of their deposit accounts with the bank holding company or its consolidated subsidiaries, so-called maintenance charges.

(2) For their failure to maintain specified minimum deposit balances.

(3) Based on the number of checks drawn on and deposits made in their deposit accounts.

(4) For checks drawn on so-called no minimum balance deposit accounts.

(5) For withdrawals from nontransaction deposit accounts.

(6) For the closing of savings accounts before a specified minimum period of time has elapsed.

(7) For accounts which have remained inactive for extended periods of time or which have become dormant.

(8) For deposits to or withdrawals from deposit accounts through the use of automated teller machines or remote service units.

(9) For the processing of checks drawn against insufficient funds, so-called NSF check charges, that the subsidiary banks of the bank holding company assess regardless of whether it decides to pay, return, or hold the check. Exclude subsequent charges levied against overdrawn accounts based on the length of time the account has been overdrawn, the magnitude of the overdrawn balance, or which are otherwise equivalent to interest (report in the appropriate subitem of item 1(a)(1), Interest and fee income on loans in domestic offices).

(10) For issuing stop payment orders. 
(11) For certifying checks.

(12) For the accumulation or disbursement of funds deposited to Individual Retirement Accounts (IRAs) or Keogh Plan accounts when not handled by the trust departments of subsidiary banks of the reporting bank holding company. Report such commissions and fees received for accounts handled by the trust departments of the holding companys banking subsidiaries or by other consolidated subsidiaries in item 5(a), Income from fiduciary activities. Exclude penalties paid by depositors for the early withdrawal of time deposits (report in item 5(1), Other noninterest income, or deduct from the interest expense of the related category of time deposits, as appropriate).

\section{Further Robustness Checks}

\section{C.1 Interchange Income Regressions for Firms Above the Thresh- old}

As discussed in section 4.1, only firms with $\$ 25,000$ of interchange income that exceeds 3 percent of other noninterest income are required to report interchange income. However, several firms not meeting this threshold still report interchange income. In order to avoid any biases, table 18 shows the regression results excluding these voluntary reporters. The results still hold. Interchange income declines in the range of 31 to 33 percent.

Table 18: Interchange Income Regressions - Only Firms Above the Threshold

\begin{tabular}{|c|c|c|c|c|}
\hline Variables & $\begin{array}{c}\text { Consistent } \\
1\end{array}$ & $\begin{array}{c}\text { Interchange Inc. } \\
2\end{array}$ & $\begin{array}{c}\text { Consistent } \\
3\end{array}$ & $\begin{array}{c}\text { Interchange Inc. } \\
4\end{array}$ \\
\hline Durbin $\times$ Treat & $\begin{array}{r}-0.394^{* * *} \\
(0.0483)\end{array}$ & $\begin{array}{r}-0.378^{* * *} \\
(0.0479)\end{array}$ & $\begin{array}{r}-0.394^{* * *} \\
(0.0485)\end{array}$ & $\begin{array}{r}-0.381^{* * *} \\
(0.0480)\end{array}$ \\
\hline Constant & $\begin{array}{r}0.118^{* * *} \\
(0.0234)\end{array}$ & $\begin{array}{r}0.118^{* * *} \\
(0.0233)\end{array}$ & $\begin{array}{r}0.131^{* * *} \\
(0.0235)\end{array}$ & $\begin{array}{r}0.131^{* * *} \\
(0.0234)\end{array}$ \\
\hline Fixed Effects? & No & No & Yes & Yes \\
\hline Observations & 9,682 & 9,829 & 9,682 & 9,829 \\
\hline Firms & 652 & 662 & 652 & 662 \\
\hline R-squared & 0.029 & 0.028 & 0.189 & 0.190 \\
\hline Adj. R-squared & 0.028 & 0.027 & 0.129 & 0.129 \\
\hline
\end{tabular}

Robust standard errors in parentheses are clustered at the firm level.

Year-quarter dummies are suppressed.

*** $\mathrm{p}<0.01,{ }^{*} * \mathrm{p}<0.05,{ }^{*} \mathrm{p}<0.10$ 